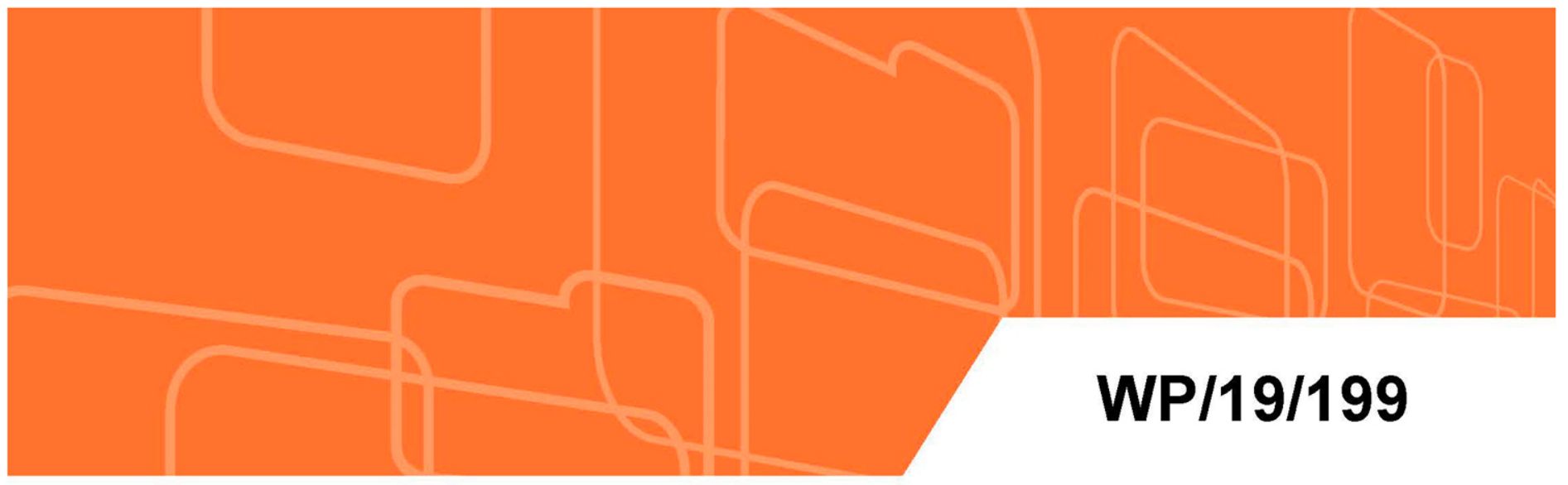

IMF Working Paper

\title{
US vs. Euro Area: Who drives cross border bank lending to EMs?
}

by Eugenio Cerutti and Carolina Osorio Buitron

IMF Working Papers describe research in progress by the author(s) and are published to elicit comments and to encourage debate. The views expressed in IMF Working Papers are those of the author(s) and do not necessarily represent the views of the IMF, its Executive Board, or IMF management. 


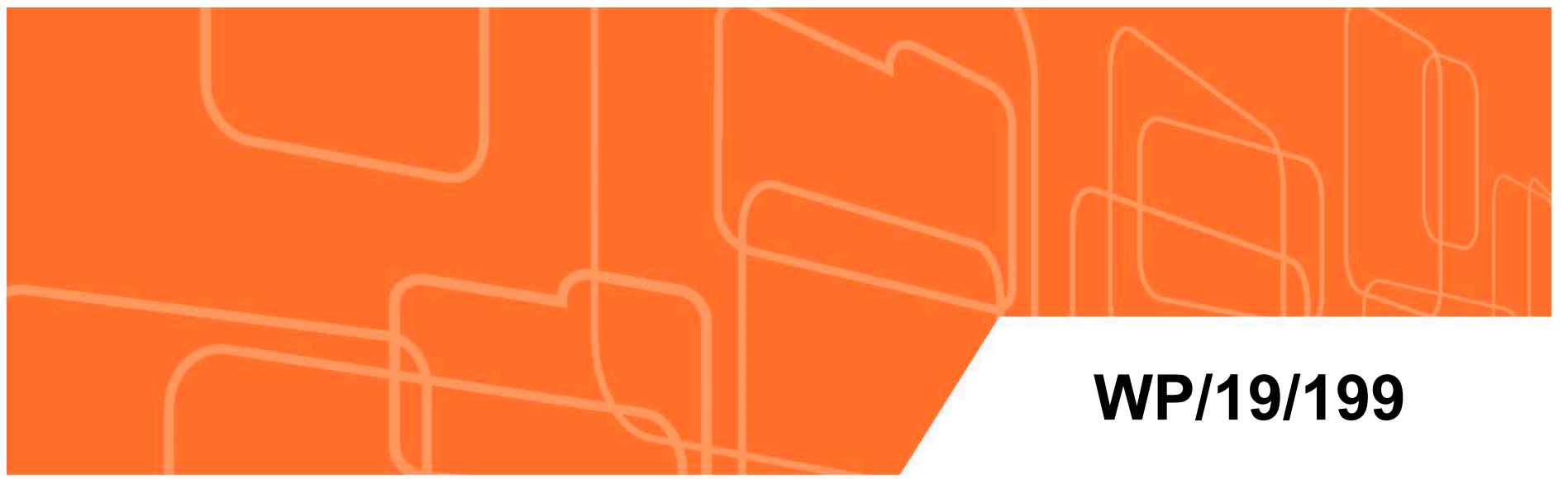

\section{IMF Working Paper}

\section{US vs. Euro Area: Who drives cross border bank lending to EMs?}

by Eugenio Cerutti and Carolina Osorio Buitron

IMF Working Papers describe research in progress by the author(s) and are published to elicit comments and to encourage debate. The views expressed in IMF Working Papers are those of the author(s) and do not necessarily represent the views of the IMF, its Executive Board, or IMF management. 


\title{
IMF Working Paper
}

Research Department

\section{US vs. Euro Area: Who drives cross border bank lending to EMs? Prepared by Eugenio Cerutti and Carolina Osorio-Buitron ${ }^{1}$}

Authorized for distribution by Helge Berger

September 2019

\section{IMF Working Papers describe research in progress by the author(s) and are published to elicit comments and to encourage debate. The views expressed in IMF Working Papers are those of the author(s) and do not necessarily represent the views of the IMF, its Executive Board, or IMF management.}

\begin{abstract}
This paper analyzes the drivers of cross-border bank lending to 49 Emerging Markets (EMs) during the period 1990Q1-2014Q4, by assessing the impact of monetary, financial and real sector shocks in both the US and the euro area. The literature has traditionally highlighted the influence of US monetary policy on driving cross-border bank flows, and more recently the importance of both US and Euro Area (EA) financial/banking sectors' related variables. Our contribution is the simultaneous analysis of the role of these US and EA drivers, as well as their interactions with real sector shocks. We corroborate the negative impact of US monetary policy tightening on cross-border lending to EMs, but we find that EA monetary policy seems to have an impact mostly on Emerging Europe, reflecting the fact that cross-border lending to most other EM regions is dollar denominated. We also find that real sector shocks in both the US and EA trigger an increase in cross-border lending, but less in EA when modeling the financial sector. Finally, for financial sector shocks, such as those associated with a decrease in bank leverage, our results indicate a broad-based overall contraction of cross-border lending if the shock originates in the US, and heterogenous effects across borrowing regions if the shock originates in the EA.
\end{abstract}

JEL Classification Numbers: F21, F34, G15, G18, G21, G28

Keywords: cross-border bank lending, emerging markets, global banks

Author's E-Mail Address: Ecerutti@,imf.org, Cosoriobuitron@imf.or

\footnotetext{
${ }^{1}$ Cerutti and Osorio-Buitron are both at the International Monetary Fund (IMF). We are grateful to Shekhar Aiyar, Nathaniel Arnold, Helge Berger, Ricardo Correa, Rodrigo Cubero, Heedon Kang, Junko Koeda, as well as the 28th NBER-TCER-CEPR conference (Tokyo, July 2019) and Federal Reserve Board IFS seminar participants for useful comments, and to Haonan Zhou for help with the data.
} 


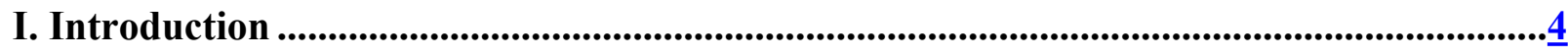

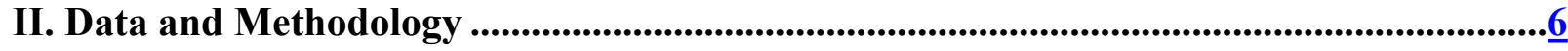

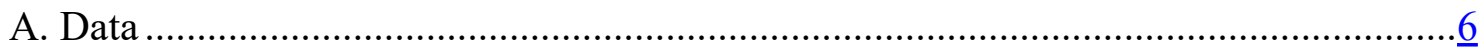

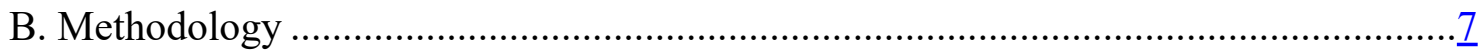

B.1. Identification through sign restrictions ............................................ 8

B.2. Identification through recursive ordering in a single economy model .......14

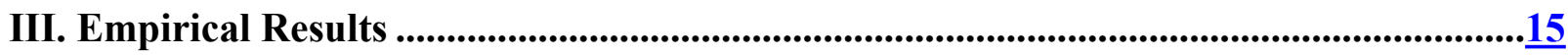

A. Results using sign restriction method for identification ..................................

B. Results using recursive ordering method for identification .................................18

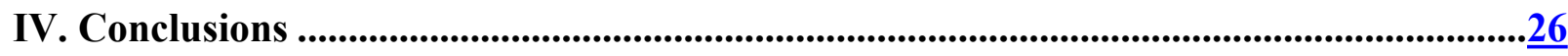

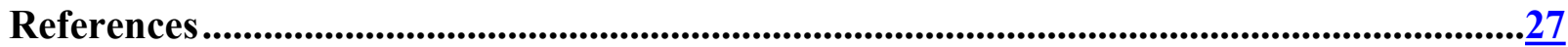

\section{TABLES}

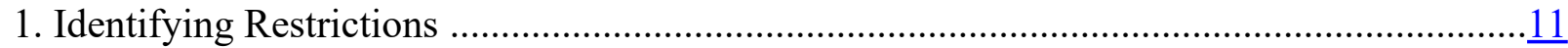

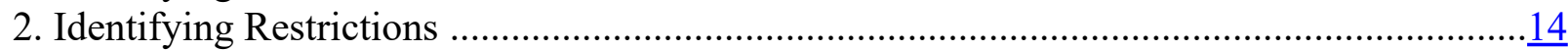

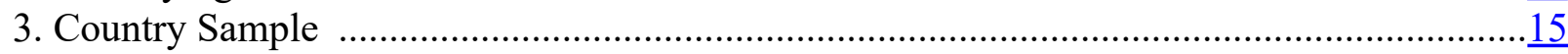

4. Responses of cross border lending to emerging economies to monetary shocks .................

5. Responses of cross-border lending to emerging economies to real shocks .........................23

6. Responses of cross-border lending to emerging economies to financial shocks ..................25

\section{FigURES}

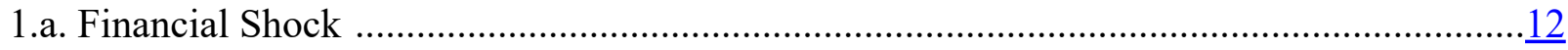

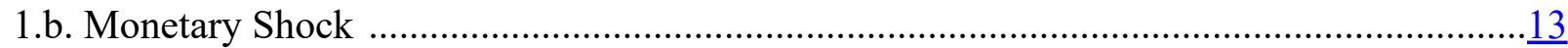

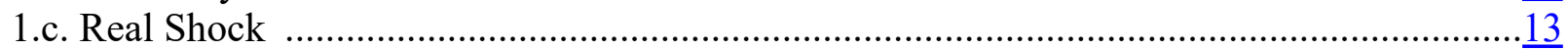

2. Responses to monetary shocks ............................................................................... $\frac{16}{17}$

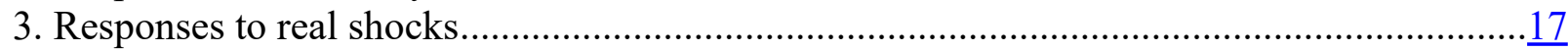

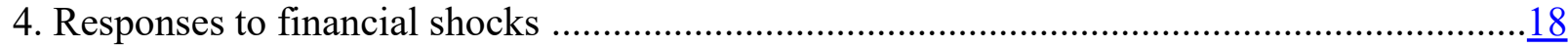

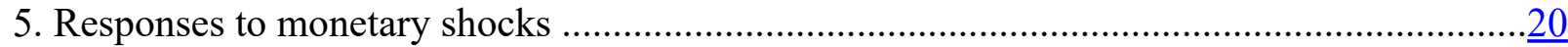

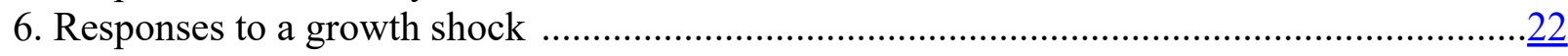

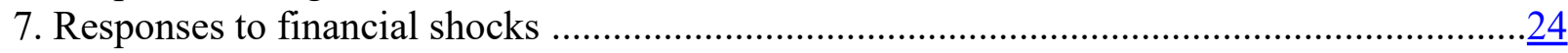

\section{APPENDIX}

A. Evolution of the Domestic Variables and Spillovers to EMs 


\section{INTRODUCTION}

The literature (e.g., Calvo et al., 1996, Bruno and Shin, 2015a) has traditionally seen monetary conditions in the United States (US) as playing a key role in the evolution of cross-border credit to EMs. More recently, Forbes and Warnock (2012) and Rey $(2013,2015)$ relate the evolution of cross-border bank lending to investors' uncertainty and risk aversion, as captured by the US VIX, and Bruno and Shin (2015b) relate it to US banks' risk attitudes and funding conditions as proxied by the leverage of US broker-dealers. In addition, Cerutti, Claessens, and Ratnovski (2017) find that European monetary and banking sector indicators are also important drivers of cross-border lending to EMs, which is in line with the fact that most cross-border lending to EMs is carried out by European banks. The simultaneous interaction of all these different drivers has yet to be explored. We attempt to fill this gap in the literature.

The aim of this paper is to simultaneously explore, US and Euro Area (EA) drivers of crossborder lending, while controlling for lender and borrower changes in economic activity. This is important not only because US and EA monetary responses are a function of domestic cyclical conditions, but also because US and EA financial/banking conditions are not independent in a globalized economy. For example, it is likely that US monetary policy affects both US and EA banks' conditions given the importance of dollar funding for international banks. In addition, financial/banking sector fundamentals could be either capturing cyclical factors (e.g., weak activity affecting banks' balance sheets) or more idiosyncratic banking shocks (e.g., an increase in bank regulation). Knowing which variables in the lender-countries matter as drivers of crossborder bank lending to EMs is especially relevant in the current context, as monetary policies in the US and EA are at different points of their monetary cycles, and their banking sectors have recovered differently from the crisis, owing to differences in the macroeconomic conditions of these two economic blocs.

In this context, we estimate a couple of models where US and EA shocks are jointly identified, through contemporaneous sign restrictions, and used in two-economy panel VAR models. These models have two sets of variables in each model. The first set includes an external set of variables from either US or EA, capturing monetary policy, financial variables, and economic cyclical conditions. The second set includes variables in the EM borrowing country, namely GDP growth, the real effective exchange rate, and received cross-border bank flows. In the first model we focus on monetary and cyclical external shocks, with the identifying assumptions following from a subset of the over-identifying restrictions in Ehrmann, Fratzcher and Rigobon (2011). A further enlargement of the model includes financial/banking shocks through the introduction of a sign restriction identification based on Bernanke and Blinder (1988)'s model. ${ }^{2}$ The estimated external shocks are then used in the panel two-economy VAR estimations.

\footnotetext{
${ }^{2}$ Bernanke and Blinder (1988) model includes three type of assets (money, bonds, and bank loans), hence, it has two types of interest rates: bond yield and bank lending rates. These features allow us to identify the impact of real, monetary and macroprudential shocks into bond yields, lending rates, and stock prices.
} 
The results highlight the positive impact of real shocks originating in the EA, as well as in the US, but to a lower degree, on cross-border bank lending to EMs. ${ }^{3}$ Both a US and a EA monetary tightening has a significant negative impact on cross-border lending, but the results indicate that this is especially the case for US monetary policy because EA monetary policy seems to be only significant in the case of cross-border bank flows to European EMs. This is to be expected given that loans and funding are mostly in US dollars in the remaining EMs in our sample. ${ }^{4}$ In the more general model, monetary and real sector policy shocks in the US as well as monetary shocks in the EA are very similar, independently of whether we add the financial sector. However, this is not the case for real shocks in the EA, which lose importance and statistical significance when including the financial sector. The universal bank model in the EA seems to be more correlated with the economic cycle than the financial intermediaries in the US. Hence, without including the financial sector, the small model seems to assign a larger role to real sector shocks than warranted. The impact of the financial sector on cross-border lending is also interesting. A negative financial shock in the US triggers a decline in cross-border lending to EMs, especially lending to EMs banks. While this is also the case for EA financial shocks propagating to Latam, Asia, and banks in Emerging Europe, the impact of the financial shocks in EA triggers an increase of cross-border lending to the non-bank sector in Europe, probably due to regulatory arbitrage. ${ }^{5}$

Our results complement and contribute to the literature in three main aspects. First, they support the papers which agree that a US monetary tightening decreases cross-border bank flows to EMs. The evidence in the literature on US monetary policy is mixed. Many papers find that crossborder lending responds negatively to a tightening in US monetary policy (Gianetti and Laeven 2012, Bruno and Shin 2015b, Brauning and Ivashina 2017, etc.); others find monetary policy variables are not always significant, or do not consistently have the same sign (e.g., Goldberg 2002, Cetorelli and Goldberg 2012), with some even finding opposite signs (e.g., Jeanneau and Micu 2002, and Correa et al. 2016). Our results were consistently negative not only in the case of overall lending to EMs, but also across regional breakdowns and type of borrowers (banks and non-banks).

Second, but not less important, they put into context the findings of Cerutti, Claessens and Ratnovski (2017) on the importance of taking into account EA shocks. In this context of performing an analysis that takes into account the endogeneity of the different key variables within and between the US and EA, our results validate their results that European bank conditions are important, but we do find in our approaches that US financial shocks (e.g., triggering a decrease in bank leverage) on cross-border lending are as important, and even more consistently negative than EA financial shocks. We also confirm their finding that US monetary

\footnotetext{
${ }^{3}$ We also estimate the panel VAR using a more traditional recursive ordering of either US or EA vector variables. Results are somewhat similar but these models do not allow for interaction between US and EA factors (either US or EA variables are used in the estimations).

${ }^{4}$ See McCauley et al. 2015 and Avdjev and Takas 2016 for an analysis of the importance of the US dollar in global banking, and Shin (2012) for the large role of European banks in intermediating (dollar- and other-denominated) cross-border credit.

${ }^{5}$ The financial shock is not just representative of policies. This shock can reflect policies working through the demand side (e.g., LTV limits), the supply side (e.g. capital requirements), as well as financial frictions or preference shifts. See discussion in Section II.
} 
policy plays a more global role than EA monetary policy. Moreover, our results even strengthen their argument that this is driven by the US dollar as the dominant currency in cross-border lending, since we find that EA monetary shocks matter in the case of Emerging Europe where cross-border lending is mostly denominated in euros. This is in line with the recent analysis by Avdjiev et al (2019) that global funding currencies play a key role in international monetary policy transmission.

Last, but not least, our results provide further evidence on how the impact of tightening macroprudential measures usually results in lower cross-border lending, but not always. Both of our models capture that a negative EA financial shock would increase cross-border lending in Emerging Europe. This latter evolution would be consistent with the type of regulatory arbitrage highlighted by Houston et al (2012), which finds that tighter regulation in the source country encourages credit outflows. On the other hand, Aiyar et al. (2014) find that an increase in capital requirements in the $\mathrm{UK}$ is associated with a reduction in some types cross-border lending. More generally, Buch and Goldberg (2017), summarizing several country and cross-country studies using confidential bank level datasets, highlight that the sign of spillovers onto cross-border lending can be positive or negative, indicating that different constraints are binding for different types banks and that banks substitute between different types of activities.

In the context of divergence in the economic cycle in US and EA (e.g., the recovery has been stronger in the US after the Global Financial Crisis which resulted in an earlier tightening of the US monetary policy than in the EA), our findings have clear policy implications. Even though the US Federal Reserve and the European Central Bank set their policies as a function of the economic cycle in their respective areas, their effects are different due to the nature of the currency denomination of cross-border lending (mostly US dollar denominated outside Emerging Europe), as well as the business and funding model of European banks, which play a large role in cross-border lending. The tightening in the US monetary policy will most likely trigger a reduction in cross-border banking flows to EMs (especially through the appreciation of the US dollar), which could be partially offset as a function of the evolution of the real economy in EA as well as improvements in US and EA bank fundamentals, rather than a more expansionary EA monetary policy.

The rest of the paper proceeds as follows. Section II describes the data and the empirical methodology we use, while the first part of section III presents the empirical results. The last section concludes with broader lessons and outstanding issues for policy and research.

\section{DATA AND METhODOLOGY}

\section{A. Data}

We use three sets of data in our empirical estimations. First, we use BIS Locational data for mapping cross-border bank flows, as conceptually those data conform most closely to the notion that conditions in specific financial center countries might affect flows to other countries, including flows to local subsidiaries. In addition, as highlighted in Cerutti, Claessens, and Ratnovski (2017), the locational data have other unique advantages in our context. First, they 
offer a time series from 1990 to the present, which is longer than the datasets used in most existing studies. Second, locational data offers the possibility to construct exchange rateadjusted series. ${ }^{6}$ Adjusted series better capture actual choices to change cross-border positions, as opposed to the unadjusted US dollars claims series used in most other studies, which are affected by exchange rate movements and thus reflect not only the net effects of loans extended and repaid over the period (excluding intra-period flows). We collect these data for the liabilities of 49 EM borrowing countries and also differentiate between borrowing by banks and non-banks in these countries. This latter breakdown allows for robustness checks that explore whether global financial conditions explain cross-border banking flows to banks in the same way they do for flows to non-banks. A priori, we expect that conditions within financial centers might have a weaker relationship with flows to non-banks than with those to banks. ${ }^{7}$

The second dataset covers US and EA real, monetary and financial variables. Specifically, we collect, for each of the two economies, the stock market volatility implied by the options markets (VIX), bank leverage (broker-dealer leverage for the United States and the leverage of large, systemically important banks in the EA), TED spread (3-month interbank rate minus 3-month government bond yield), term spread (10-year minus 3-month government bond yields), real policy rate (deflated with CPI), and GDP growth, and real effective exchange rates. The sources of these measures are summarized in Table A1 in the appendix, presented separately for the US, and EA.

The third dataset covers the variables used in the sign restriction analysis. The datasources are Haver and Bloomberg. For the US the long-term bond yield series is the 10-year US treasury bond yield, and the equity price series are the S\&P 500 composite, both expressed in logarithms. For the euro area, long-term bond yields correspond to Euroarea 10-year government benchmark bond yield from the ECB, and the equity price series are the Euro Stoxx 50, both expressed in logarithms. Note that, for the identification of financial shocks as a proxy of bank lending rates, we use mortgage market interest rates in US and EA.

\section{B. Methodology}

Following the literature, cross-border lending flows to emerging economies can be influenced by both push (global) and pull (emerging market domestic) factors. Accordingly, our model includes a vector of global variables $\left(F_{t}\right)$, and another of emerging market variables $\left(Y_{i, t}\right)$.

\footnotetext{
${ }^{6}$ Locational data series publicly available from the BIS consist of (non-adjusted) stock of claims and exchange rateadjusted flows. Taking the latest stock figures as a baseline, we derive exchange rate-adjusted stocks for each quarter using the exchange rate-adjusted flows. Data for performing currency adjustments is not easily available for BIS Consolidated Banking Statistics (see Cerutti 2015 for more details).

${ }^{7}$ For example, from the analysis of the composition of cross-border banking flows in Cerutti, Hale, and Minoiu (2015), we know that cross-border syndicated loans to non-banks tend to have longer maturities than other crossborder claims (e.g., intragroup bank lending) and so might be less affected by short-term changes in pull factors.
} 
We estimate a Panel VAR model that takes the following form:

$$
\left(\begin{array}{cc}
A_{0}^{F} & 0 \\
A_{0}^{F Y} & A_{0}^{Y}
\end{array}\right)\left(\begin{array}{c}
F_{t} \\
Y_{i, t}
\end{array}\right)=\gamma_{i}+\sum_{l=1}^{L}\left(\begin{array}{cc}
A_{l}^{F} & 0 \\
A_{l}^{F Y} & A_{l}^{Y}
\end{array}\right)\left(\begin{array}{c}
F_{t-l} \\
Y_{i, t-l}
\end{array}\right)+U_{i, t}
$$

The block of global variables is comprised of variables from either the US or the EA. The emerging market block, $Y_{i, t}$, includes domestic GDP, the real effective exchange rate, and crossborder bank lending flows to the each economy $i . \quad \gamma_{i}$ is a country-specific intercept; and $A_{0}^{F}$ and $A_{0}^{Y}$ are lower-diagonal matrices, such that the restrictions on the contemporaneous relationships among variables imply a recursive ordering. The latter ensures that $U_{i, t}$ is a vector of uncorrelated iid shocks.

The $\mathbf{0}$ matrix on the right-hand side of equation (1) implies that emerging market domestic developments have a negligible effect on global factors. Thus, shocks in the US or the EA are primarily identified by exploiting the small-economy properties of emerging markets. Since we are interested in the effects of global factors on emerging market variables, identification of domestic shocks at the emerging economy level is not necessary.

By contrast, the identification of global shocks is of first-order importance. The effect of changes in global factors on cross-border lending to emerging economies likely depends on the underlying shock. For instance, tighter monetary conditions in the US/EA are likely to affect cross-border lending differently, depending on whether the tighter stance corresponds to an exogenous shock or an endogenous response to better economic prospects. We focus on three types of global shocks: real (capturing changes in cyclical conditions), monetary (capturing changes in the stance of monetary policy and inflationary pressures) and financial (capturing shocks that affect banks willingness to lend when the monetary policy stance is held constant and is unrelated to changes in the stance of monetary policy). To identify these shocks we follow two methodologies. First, in our two main models (small and large), US and EA shocks are jointly identified through sign restrictions that exploit information in asset prices and interest rates. Second, a recursive ordering of either the US or EA vector of variables is presented as a way to benchmark the sign-restrictions results. 


\section{B.1 - Identification through sign restrictions}

In order to properly account for the interactions between the US and EA, we follow a two-step emprical strategy:

- First, we identify structural shocks in the US and the EA, by estimating a two economy VAR model with contemporaneous sign restrictions using the methodology developed by Rubio-Ramirez et al. (2005). The identifying assumptions exploit information in asset price movements as in Ehrman, Fratzcher and Rigobon (2011), EFR hereafter. The advantage of this approach is that US and EA shocks are jointly identified, thus taking account of relationships between these two economies.

- Second, the identified shocks are introduced as exgenous global variables in the Panel VAR, and their effects on cross-border lending to emerging market are examined, while taking account of the effects of global shocks on emerging markets' GDP growth and real effective exchange rates.

We specify two sign restricted VAR models to identify global shocks. In the small model, we focus only on the identification of monetary and cyclical shocks, consistent with what has been done previously in the literature, as in EFR (2011) and Matheson and Stavrev (2014). We then extend the framework to identify financial shocks. The comparison between these two specifications sheds light on both, the importance of financial shocks and the role of the financial sector in the transmission of real and monetary shocks.

\section{$\underline{\text { Small model }}$}

In the first specification, money and cyclical shocks in the US and EA are identified through sign restrictions, based on a subset of assumptions in EFR. ${ }^{8}$

The reduced-form model is given by equations (2) - (5).

$R_{t}^{U S}=\alpha_{0}+\alpha_{1} R_{t-1}^{U S}+\alpha_{2} S_{t-1}^{U S}+\alpha_{3} R_{t-1}^{E A}+\alpha_{4} S_{t-1}^{E A}+\varepsilon_{t}^{R, U S}$

$S_{t}^{U S}=\delta_{0}+\delta_{1} R_{t-1}^{U S}+\delta_{2} S_{t-1}^{U S}+\delta_{3} R_{t-1}^{E A}+\delta_{4} S_{t-1}^{E A}+\varepsilon_{t}^{S, U S}$

$R_{t}^{E A}=\beta_{0}+\beta_{1} R_{t-1}^{U S}+\beta_{2} S_{t-1}^{U S}+\beta_{3} R_{t-1}^{E A}+\beta_{4} S_{t-1}^{E A}+\varepsilon_{t}^{R, E A}$

$S_{t}^{E A}=\rho_{0}+\rho_{1} R_{t-1}^{U S}+\rho_{2} S_{t-1}^{U S}+\rho_{3} R_{t-1}^{E A}+\rho_{4} S_{t-1}^{E A}+\varepsilon_{t}^{S, E A}$

where $R^{j}$ and $S^{j}$ denote, respectively, the 10-year government bond yield and the logarithm of the stock price index of economy $j=\{U S, E A\}$. The model is estimated in levels. ${ }^{9}$

\footnotetext{
${ }^{8}$ While EFR impose the restrictions on the contemporaneous coefficient matrix, we impose restrictions on the impulse response function which must be satisfied contemporaneously.

${ }^{9}$ While we cannot reject the hypothesis that the variables in the model have a unit root, they are cointegrated; hence, estimating the model in levels incorporates any cointegrating relationships without the need to specify a VECM, and examination of the impulse response functions reveals that the responses go back to the steady-state values. To sum up, estimating the model without first-differencing is acceptable.
} 
The reduced form residuals $\varepsilon_{t}=\left[\varepsilon_{t}^{R, U S}, \varepsilon_{t}^{S, U S}, \varepsilon_{t}^{R, E A}, \varepsilon_{t}^{S, E A}\right]^{\prime}$ of the system above combine structural real and monetary shocks from both the US and euro area $\mu_{t}=$ $\left[\mu_{t}^{R, U S}, \mu_{t}^{S, U S}, \mu_{t}^{R, E A}, \mu_{t}^{S, E A}\right]^{\prime}$. That is,

$\varepsilon_{t}^{R, U S}=\alpha_{5} \mu_{t}^{R, U S}+\alpha_{6} \mu_{t}^{S, U S}+\alpha_{7} \mu_{t}^{R, E A}+\alpha_{8} \mu_{t}^{S, E A}$

$\varepsilon_{t}^{S, U S}=\delta_{5} \mu_{t}^{R, U S}+\delta_{6} \mu_{t}^{S, U S}+\delta_{7} \mu_{t}^{R, E A}+\delta_{8} \mu_{t}^{S, E A}$

$\varepsilon_{t}^{R, E A}=\beta_{5} \mu_{t}^{R, U S}+\beta_{6} \mu_{t}^{S, U S}+\beta_{7} \mu_{t}^{R, E A}+\beta_{8} \mu_{t}^{S, E A}$

$\varepsilon_{t}^{S, E A}=\rho_{5} \mu_{t}^{R, U S}+\rho_{6} \mu_{t}^{S, U S}+\rho_{7} \mu_{t}^{R, E A}+\rho_{8} \mu_{t}^{S, E A}$

Equations (6)-(9) can be expressed in matrix form as follows

$\varepsilon_{t}=Q \mu_{t}$

where $Q=\left[\begin{array}{llll}\alpha_{5} & \alpha_{6} & \alpha_{7} & \alpha_{8} \\ \delta_{5} & \delta_{6} & \delta_{7} & \delta_{8} \\ \beta_{5} & \beta_{6} & \beta_{7} & \beta_{8} \\ \rho_{5} & \rho_{6} & \rho_{7} & \rho_{8}\end{array}\right]$

The identification of structural shocks relies on a set of contemporaneous sign restrictions.

Random draws of orthonormal matrices $Q$ are generated until 1,000 parameterizations satisfying the sign restrictions are obtained, and the model for which the IRFs are closest to the median IRF is selected. The sign restrictions we impose can be classified into 2 groups, they either capture priors about domestic relationships or about cross-border spillover effects between the US and EA.

The intuition of these assumptions is better understood if we first discuss the meaning of each variable.

- A country's stock price index is a proxy for domestic demand, as a positive demand shock at home likely raises domestic equity prices.

- $\quad$ Changes in long term bond yields may be understood as reflecting money shocks, which include both changes in inflation expectations and monetary policy surprises. ${ }^{10}$

The assumptions about the domestic relationships are that: i) a positive cyclical shock increases both stock prices and bond yields, as the monetary policy is expected to tighten in response to a

\footnotetext{
${ }^{10}$ EFR include short and long term-interest rates in their model, in order to identify, respectively, monetary policy and inflation expectations shocks. However, their analysis stops in 2008 and does not cover the period in which the policy rate reaches the zero-lower bound and unconventional monetary policy is used to lower long-term rates. Furthermore, when short-term rates are at the zero lower bound, long-term rates (or the term spread) could be a better measure of monetary policy (see also Ahmed and Zlate, 2013). While the majority of our sample corresponds the period of conventional monetary policy, our "simplified" model is still consistent with the EFR framework; the authors assume that short and long-term interest rates are positively correlated, as an inflationary shock would trigger market expectations of a monetary tightening, thus raising short-term rates.
} 
positive demand shock to prevent inflation from overshooting its target (see positive signs in real US or real EA shocks in Table 1); ii) a positive money shock would increase bond yields and reduce stock prices, as exogenous increases in interest rates (or inflation expectations), lower the demand for goods and services, leading to a decline in equity prices.

Turning to international spillovers, it is assumed that there are positive cross-border spillovers within asset classes. For bond markets, the evidence suggests that this is indeed the case (see Ehrmann and Fratzcher, 2005), and for equity prices the assumption implies that stronger growth in the US is associated with better growth prospects in the euro area and viceversa. In addition, we assume that cross-border effects can not be larger than the own-economy effect, which is a reasonable assumption for advanced economies, and helps us identify the source-country of the shock. Finally, we do not impose restrictions on international cross-market relations (denoted with no signs being displayed in Table 1). We choose to remain agnostic about how an increase in bond yields affects equity prices in the EA. EFR impose exclusion restrictions for these contemporaneous relationships, but those assumptions could be too strong and bias the results

Table 1. Identifying Restrictions

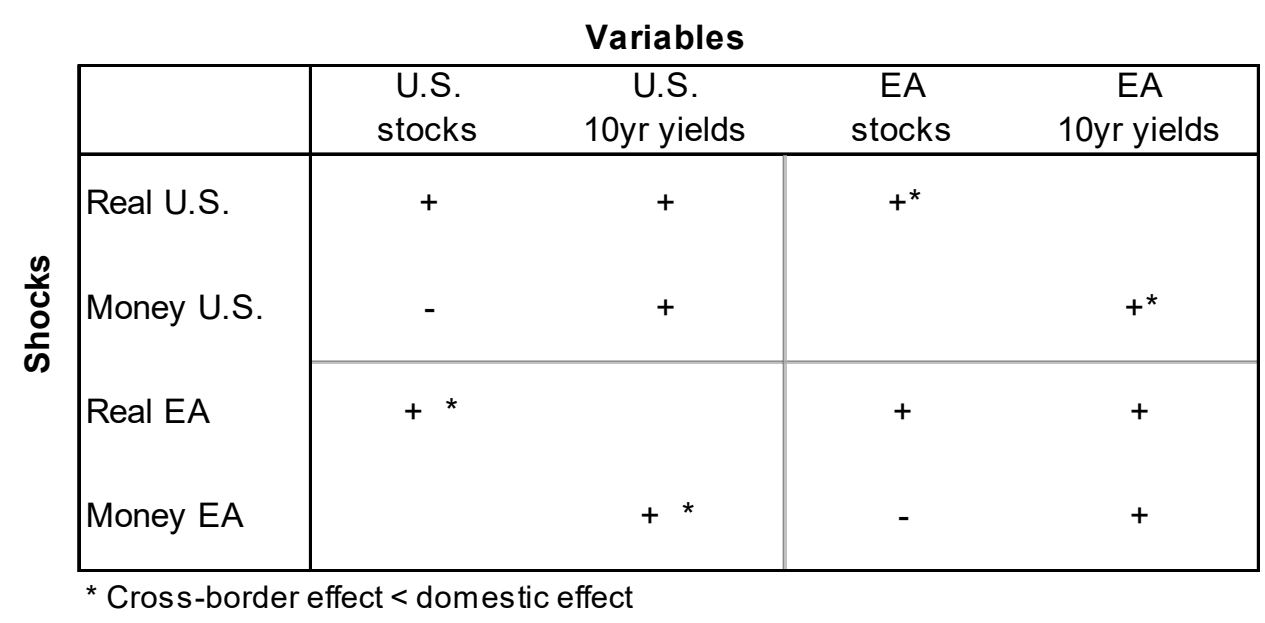

Random draws of orthonormal matrices $Q$ are generated until 1,000 parameterizations satisfying the sign restrictions are obtained. Subsequently, the model for which the IRFs are closest to the median IRF is selected.

\section{Large Model with Financial shocks}

In the last specification, the sign restricted VAR is expanded to identify financial shocks. The set of more complex identifying assumptions are based on the well-known Bernanke and Blinder (1988) theoretical model, and are displayed in Table 2. This model includes three type of assets (money, bonds, and bank loans), hence, it has two types of interest rates: bond yield and bank lending rates. Its main graphical representation is shown in Figure 1. It includes as the left-hand side chart a conventional LM curve capturing the equilibrium in the money market, and a CC (Commodity and Credit) curve, which is negative sloped in the bond yield-output Cartesian plane, like an IS curve, but it is also shifted by credit related market shocks that affect either the demand or supply of bank loans. The right-hand side charts in Figure 1 display the loan market. 


\section{Figure 1a - Financial Shock}
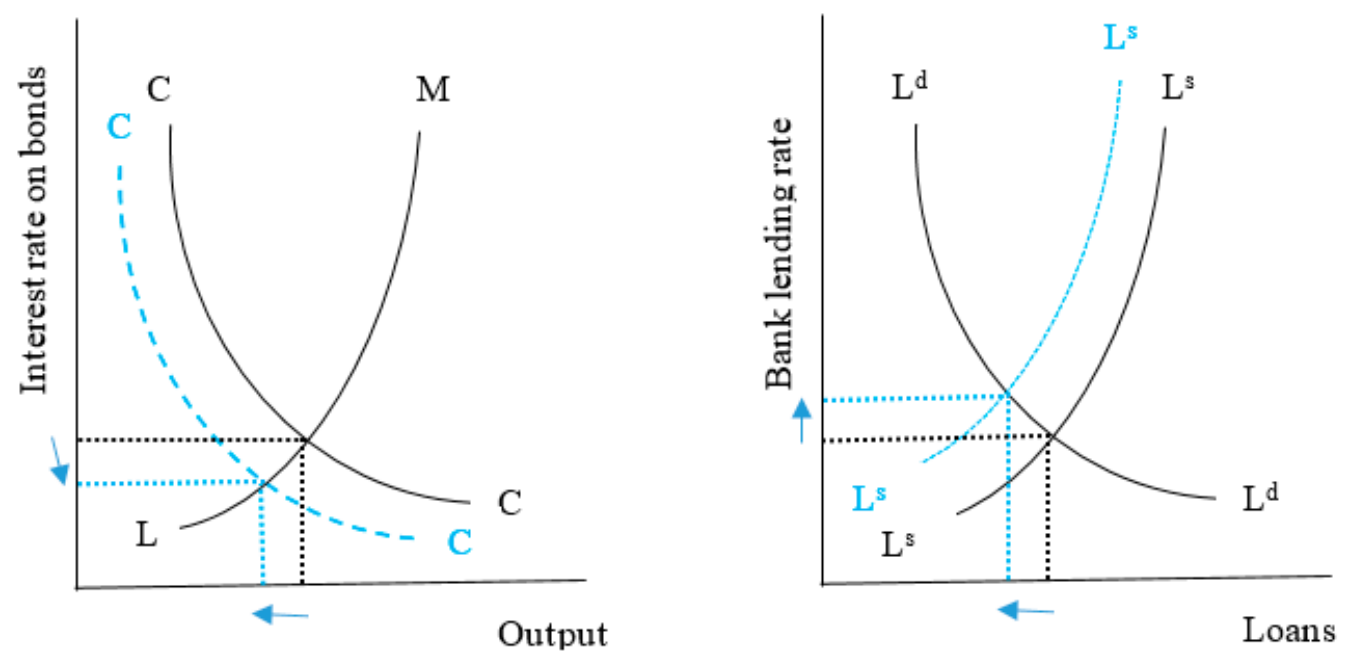

In this context, a financial shock that negatively affects the credit supply function while holding monetary policy unchanged (e.g., an increase in riskiness of loans in Bernanke and Blinder model that could also be equivalent to a macroprudential tightening measure through higher capital requirements), would trigger a downward shift of the CC curve along a fixed LM curve (see blue lines in Figure 1a). As highlighted by Turner (2016) this would be capturing macroprudential policies as measures acting directly on banks' willingness to lend while holding monetary policy unchanged. In addition to changes in capital adequacy ratios, this would capture also other prudential measures such as reserve requirements, countercyclical capital buffers, specific capital buffers, etc. Also, given that Bernanke and Blinder's CC curve is also summarizing the demand of loans, macroprudential measures targeting borrowers (e.g., Loan to Value rations (LTV) and Debt to Income ratios (DTI)) would also shift the CC curve and produce similar results. ${ }^{11}$ As the result, a tightening financial shock would reduce credit, output, and the interest rate on bonds while rising the interest rate of loans. In other words, this is capturing the transmission of a regulatory change that reduced banks willingness to lend, thus reducing the supply of credit, aggregate demand and asset prices. ${ }^{12}$

\footnotetext{
${ }^{11}$ See Cerutti, Claessens and Laeven (2017) for further analysis on the effectiveness of borrower and bank based macroprudential policies. In addition, given the broad concept, the financial shock could result from financial frictions or preference shifts.

${ }^{12}$ At the bank level, we could rationalize this process as tighter financial capital requirements standards, inducing banks to shift away from risky loans, thus raising the lending rate, and investing more in safe assets, thus lowering the government bond yields.
} 
Figure 1b - Monetary Shock
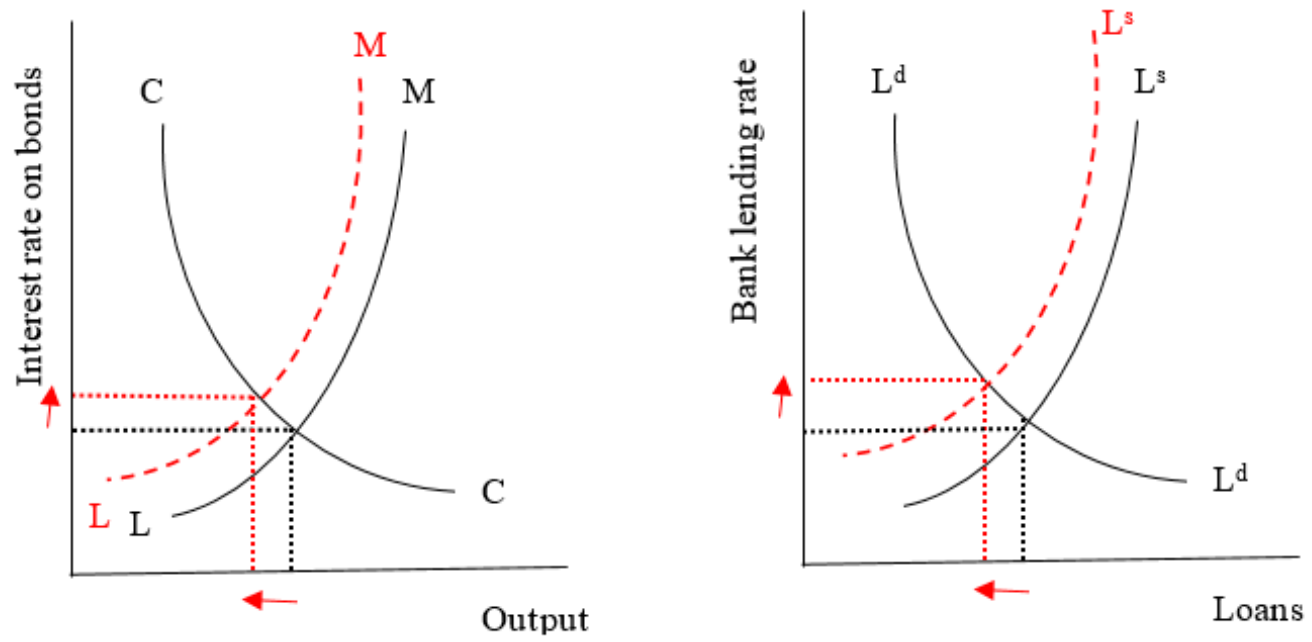

Instead, a monetary tightening in their model would translate into an increase of both the interest rate on bonds and bank lending. For example, a monetary shock would shift LM curve left along the $\mathrm{CC}$ curve (see red lines in Figure $1 \mathrm{~b}$ ), reducing output, and increasing the interest rate of bonds, which would trigger an increase in the bank lending rates. In our context, expectations of a decline in the bank lending, reduces growth prospects, leading to a decline in stock prices. Finally, a positive real shock would be associated with a shift to the right in the CC curve, and associated with increases in output, the interest rate on bonds, and bank lending rates (see green lines in Figure 1c).

Figure 1c - Real Shock
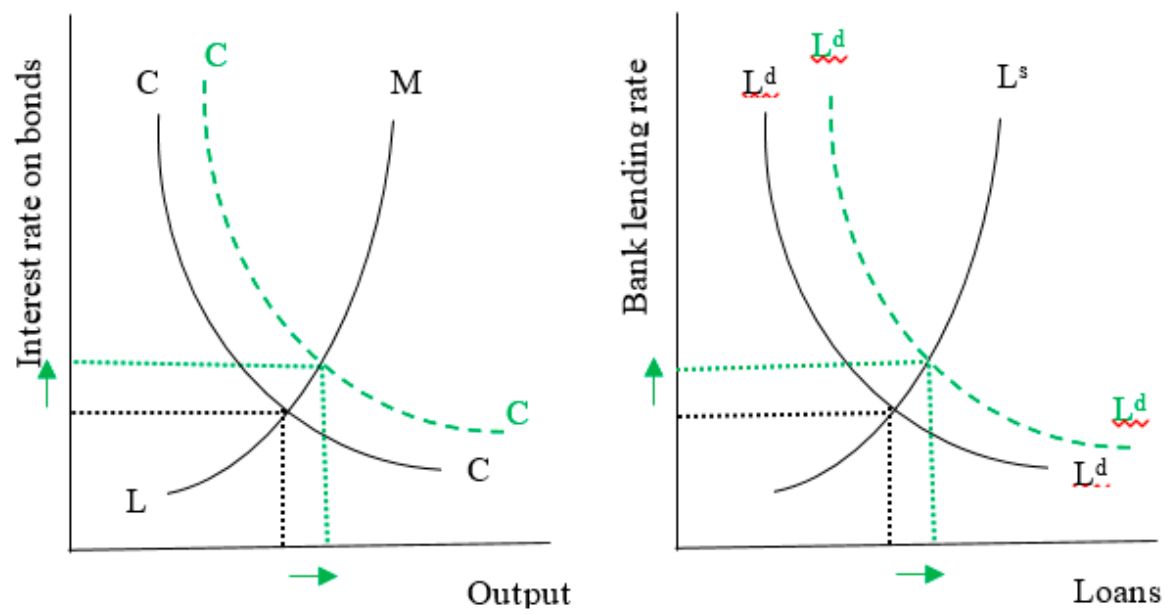
Table 2. Identifying Restrictions

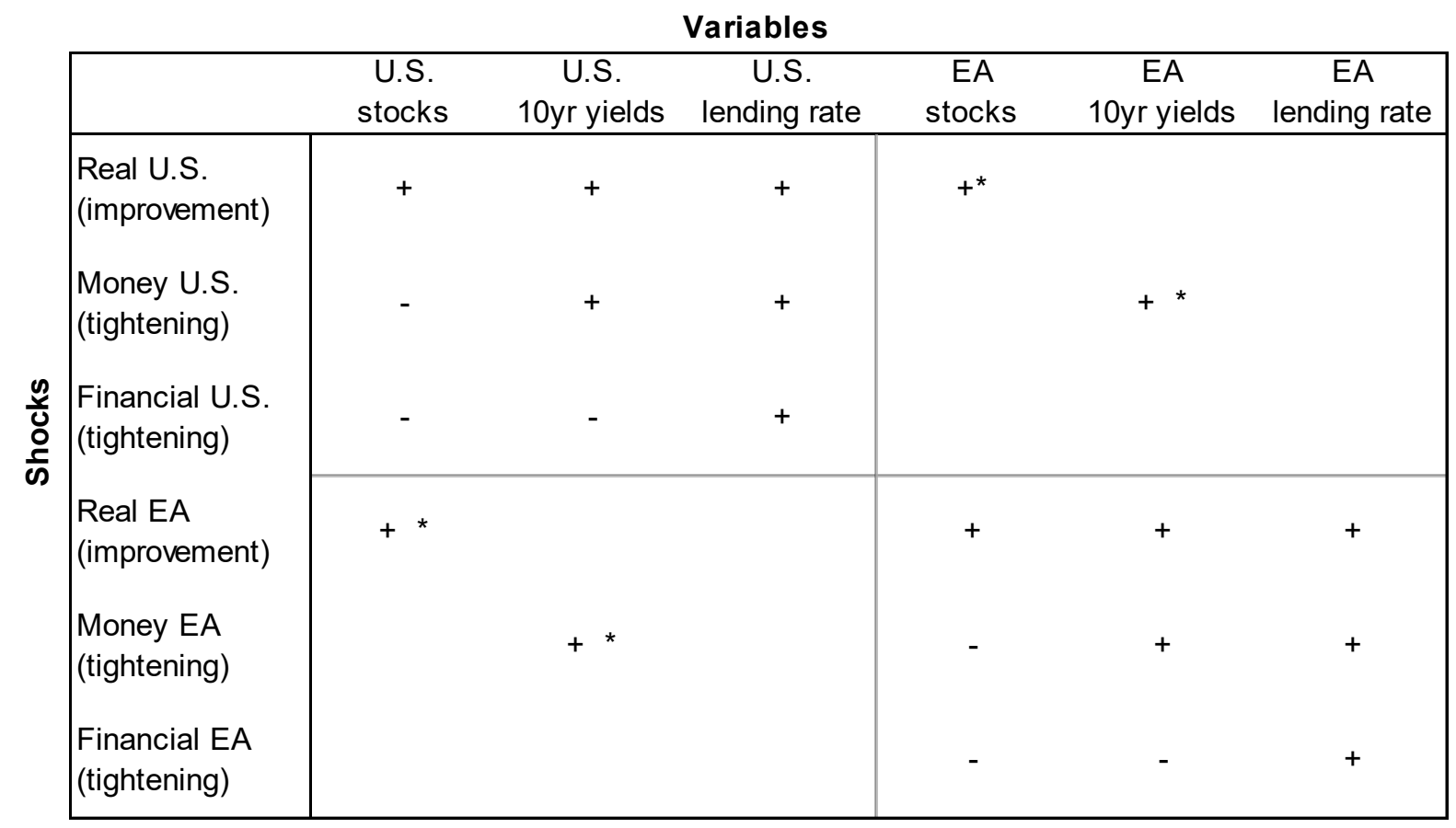

${ }^{*}$ Cross-border effect < domestic effect

\section{B.2 - Identification through recursive ordering in a single economy model}

The external variables block can be also identified through a Cholesky decomposition. We consider three types of recursive orderings. When we examine the effects of cyclical conditions, we order GDP growth first, followed by risk-appetite, the bank balance sheet indicator and the monetary policy variable. This ordering implies that GDP growth can affect risk-appetite contemporaneously, but the latter can only affect the former with a lag; risk appetite can have a contemporaneous effect on bank balance sheets, but bank balance sheets only influence riskappetite with a lag; and so on. When we assess the effects of monetary shocks, the monetary variable is placed first, followed by real GDP growth, investor risk-appetite, and the bank balance sheet variable. Finally, we examine the effects of financial shocks by placing the bank balance sheet variable first, followed by real GDP growth, risk-appetite and the monetary policy variable.

In terms of variables, monetary policy and financial variables are included, as these are indicators of global liquidity, which have been found to have important effects on cross-border lending flows (Cerutti, Claessens, and Ratnovski, 2017). The monetary policy variables are either the term spread or the real policy rate. The financial variables include a stock market volatility index to capture risk-appetite, and either bank leverage or the TED spread, which capture shocks affecting bank balance sheets. We also include a measure of economic activity (GDP growth) to control for the endogenous responses of monetary policy to US (or euro area) cyclical conditions. 


\section{EMPIRICAL RESULTS}

We use the two previously-described methodologies to identify real, monetary and financial global shocks. We start a two economy VAR model where US and EA shocks are jointly identified by exploiting information in asset prices and interest rates, and then with a recursive ordering for a vector of either US or EA variables. All our shocks are normalized to generate a change in the monetary variable of 25 basis points. This normalization facilitiates the comparison of US and EA shocks, and it also helps illustrate the importance of the underlying causes of chaning monetary conditions. For example, we can illustrate the differences between the effects of a 25 bps increase in the monetary variable due to an autnomous monetary policy or cost push-shocks, and a 25 bps increase in the monetary variable brought about by a countercyclical policy response to better growth prospects.

Given the focus of our paper, the presentation of results in this section focuses on the crossborder impact of the different shocks. Appendix A summarizes the evolution of the domestic variables as well as the spillover effects on EME's GDP growth and REER. The effects of global shocks on cross-border lending to emerging markets are discussed in more detail in this section. The panel VAR produces impulse responses for the representative emerging market economy. However, the average responses can mask variation across countries, reflecting, for example, different economic links to the US or EA. Hence, for each model specification this aspect is analyzed in two stages: first we split the sample and compare estimates across regions (see Table 3 for the country sample and region classification); second, we examine the effects of US and EA shocks on cross-border lending from these economies (rather than the aggregate lending flow into EMs).

Table 3: Country Sample

\begin{tabular}{llll}
\hline Asia & Eastern Europe & LatAm & Other \\
\hline China & Bulgaria & Argentina & Algeria \\
India & Croatia & Bolivia & Bahrain \\
Indonesia & Czech Republic & Brazil & Côte d'Ivoire \\
Malaysia & Hungary & Chile & Ghana \\
Pakistan & Iceland & Colombia & Israel \\
Philippines & Latvia & Guatemala & Jordan \\
Korea & Lithuania & Jamaica & Kuwait \\
Sri Lanka & Poland & Mexico & Libya \\
Thailand & Romania & Panama & Mauritius \\
& Russia & Paraguay & Morocco \\
& Turkey & Peru & Oman \\
& Ukraine & Venezuela & Qatar \\
& & & Saudi Arabia \\
& & & Senegal \\
& & & South Africa \\
& & & Tunisia \\
\hline
\end{tabular}




\section{A. Results using sign restriction method for identification}

\section{Monetary shocks}

Cross-border lending to EMs declines in response to a monetary tightening in the US, with significant effects across different types of lending flows and regions. This is the case either when including the financial sector (blue lines in Figure 2 below) or without the financial sector (red lines in Figure 2), especially in the case of bank to bank cross-border lending. However, if the shock originates in the EA, the negative effects are mostly economically and statistically significant for Emerging Europe. These results provide evidence in support of the importance of the exchange rate channel in the transmission of monetary policy shocks to international credit markets. Since cross-border flows are mostly denominated in dollars, the effects of US monetary policies are more broad-based. In contrast, monetary shocks in the euro area, affect cross-border lending to Emerging Europe, where cross-border flows are denominated in euros.

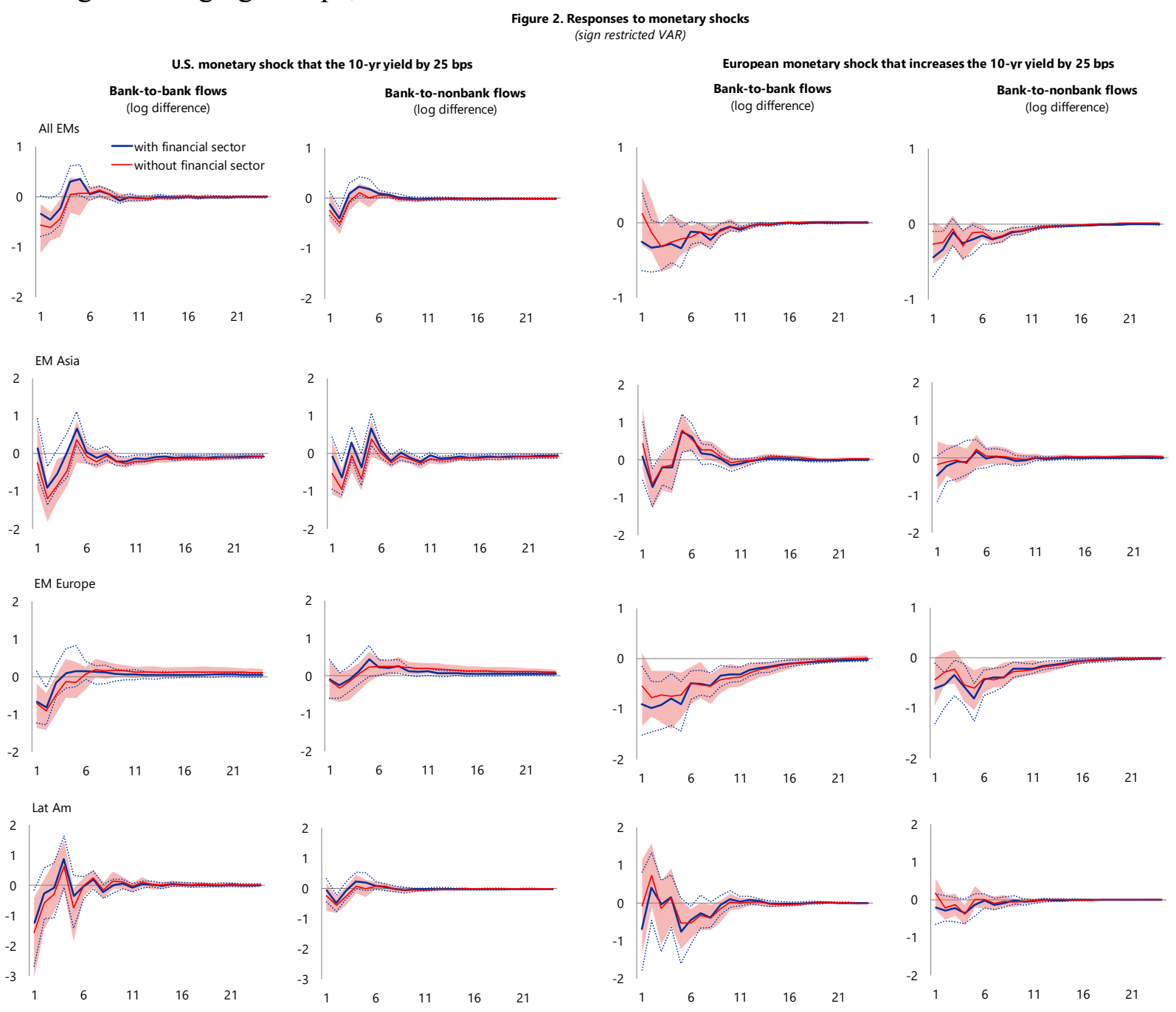

The solid line represents the point estimate, and the dashed lines represnt the 90 percent condifence interval.

Real shocks 
The sign-restricted models indicate that positive real shocks in the US or the EA tend to increase cross-border lending to EMs (see Figure 3 below). We also find that the effects on cross-border lending to EM are larger if the shock originates in the EA rather than in the US, but this differential decreases once we include the financial sector in the case of the EA (blue lines in Figure 3). This may be related to the fact that the (global) banks engaging in cross-border lending activities are mostly located in Europe, and as such, they may be more prone to rebalancing their loan portfolio in response to changes in domestic macroeconomic conditions (Cerutti et. al. 2017, Bruno and Shin, 2015a). The differences between including or not the financial sector suggest that the real sector shock is capturing part of the financial shock when the latter is not included in the case of EA. The universal bank model in the EA seems to be more correlated to the economic cycle than the financial intermediaries in US. Hence, without including the financial sector, the small model was assigning a larger role to real sector shocks than warranted.

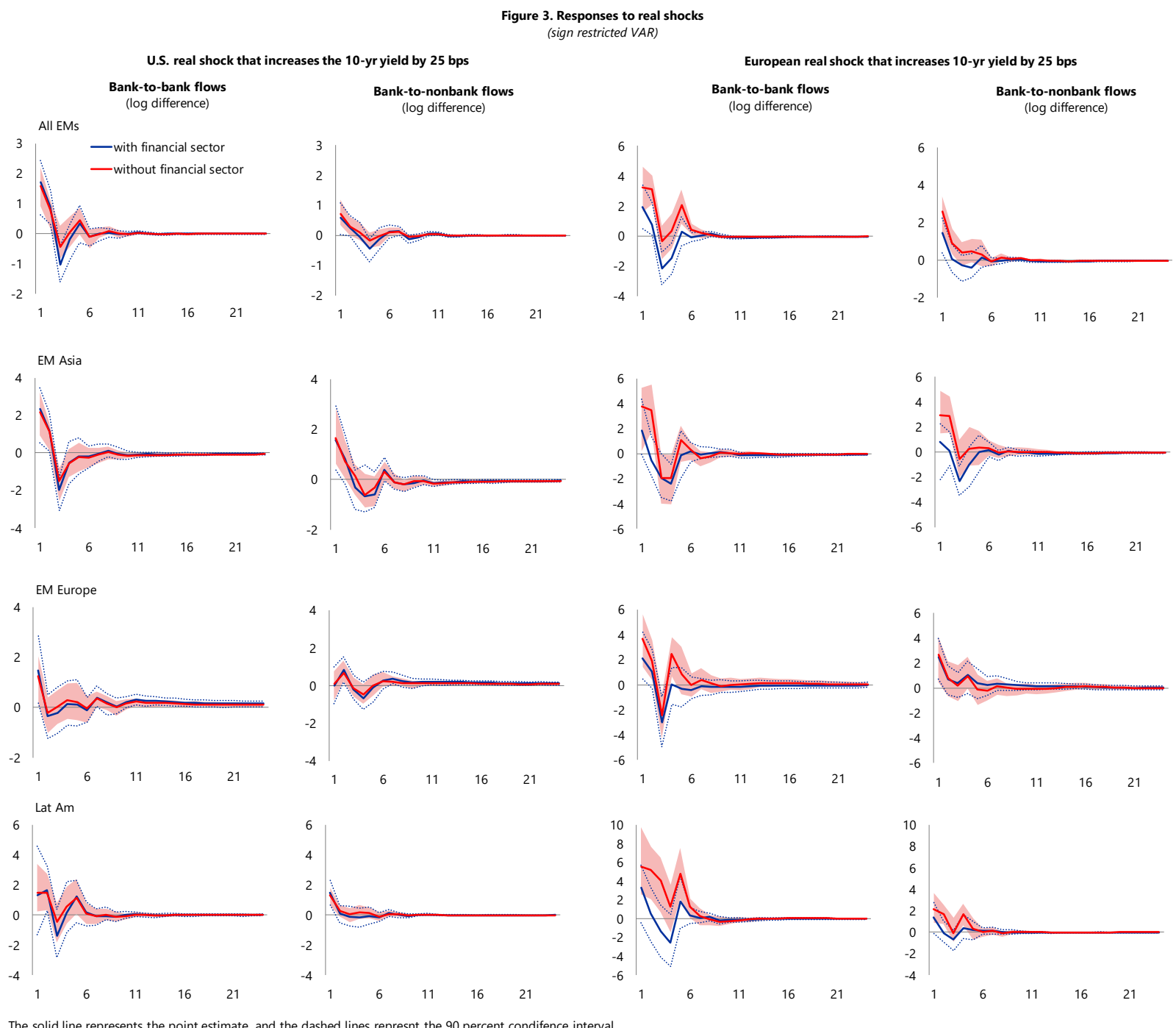




\section{Financial shocks}

A tightening financial shock reduces cross-border lending when the shock originates in the US, but this is not always the case for EA financial shocks as shown in Figure 4. There is an increase in the cross-border lending to Emerging European non-bank borrowers when the negative financial shocks originated in the EA. The effects are somewhat larger, if the shock originates in the euro area, likely because the global banks that undertake most of the cross-border lending to emerging economies are located in Europe, and are therefore more sensitive to regulatory changes in Europe than in the US.

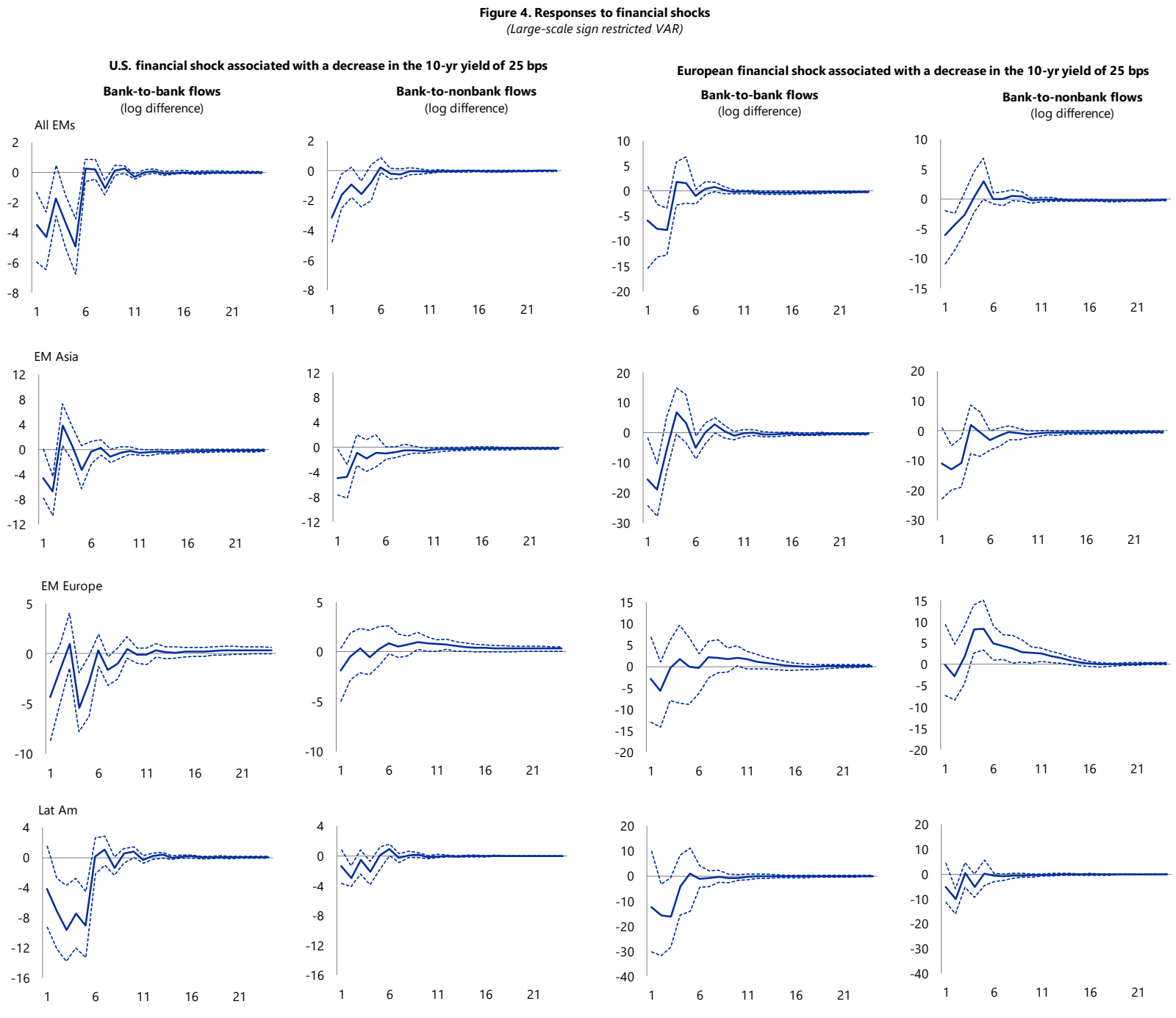

The solid line represents the point estimate, and the dashed lines represnt the 90 percent condifence interval.

\section{B. Results using recursive ordering method for identification}

In this approach, the global block is comprised of either US or EA variables, without capturing both simultaneously. For each economy, we consider a measure of monetary policy (the real policy rate rates or the term spread), a bank balance sheet variable (bank leverage or the TED 
spread, which captures bank funding costs), a variable of risk aversion as measured by the VIX (EUROVIXX in Europe) and GDP growth, to capture cyclical conditions. In the baseline specification, the monetary policy and bank balance sheet variables are given by the term spread and bank leverage, respectively. However, as presented below, the results are broadly robust to using the real policy rate as the monetary policy variable and the TED spread as a measure of bank balance sheets.

\section{Effects of monetary shocks}

Consistent with our findings using sign restriction identification, US monetary shocks that increase the domestic term spread by 25 basis points have a broader impact on cross-border lending to emerging markets than EA shocks. The impact of the US monetary shock is observed in bank-to-bank and bank-to-nonbank cross-border flows, as well as across geographic regions (see first and second columns of Figure 5 below). In general, a tightening of monetary policy in the US or EA seems to affect cross-border lending through three channels. First, the increase in the term spread in these economies, makes domestic investments relatively more attractive, ${ }^{13}$ and may therefore reduce banks incentives to lend abroad. ${ }^{14}$ Second, since the monetary shock reduces growth prospects in emerging economies, demand for cross-border loans may fall. Finally, because emerging market currencies weaken in response to the US/EA shock, borrower currency mismatches become more prominent, increasing the riskiness of cross-border loans and discouraging US/EA banks from engaging in these type of activities.

In contrast, if the shock originates in the EA, there is no evidence of a meaningful effect on cross-border lending flows to EM, except to Emerging Europe, to which lending flows drop during the first 12 quarters following the shock (see third and fourth columns of Figure 5). Confirming the sign restriction results, this points to the relevance of the exchange rate channel for the transmission of monetary policy shocks to cross-border lending. The broader and more significant effects from a shock originating in the US can be explained by the fact that international credit flows are mostly denominated in US dollars. Thus, an increase in the riskiness of cross-border loans due to larger borrower currency mismatches, are more prevalent when the weakening of emerging market currencies mirrors a strengthening of the US dollar, which, in turn, tends to occur when monetary conditions tighten in the US. Since cross-border lending to Emerging Europe is denominated in euros, the tightening of monetary policy in the EA does have a meaningful impact on lending flows to this region.

\footnotetext{
13 The term spread can be viewed as a proxy for bank profit margins, as banks engage in maturity transformation activities, by extending long-term loans that are funded with short-term contracts.

${ }^{14}$ While the analysis does not consider the change in monetary conditions of emerging economies, these are likely to change less than proportionally relative to the US or EA. In addition, since cross-border lending is riskier than domestic lending, and banks are possibly risk-averse, an improvement in domestic returns likely leads to a substitution of banks' lending portfolio toward domestic loans.
} 


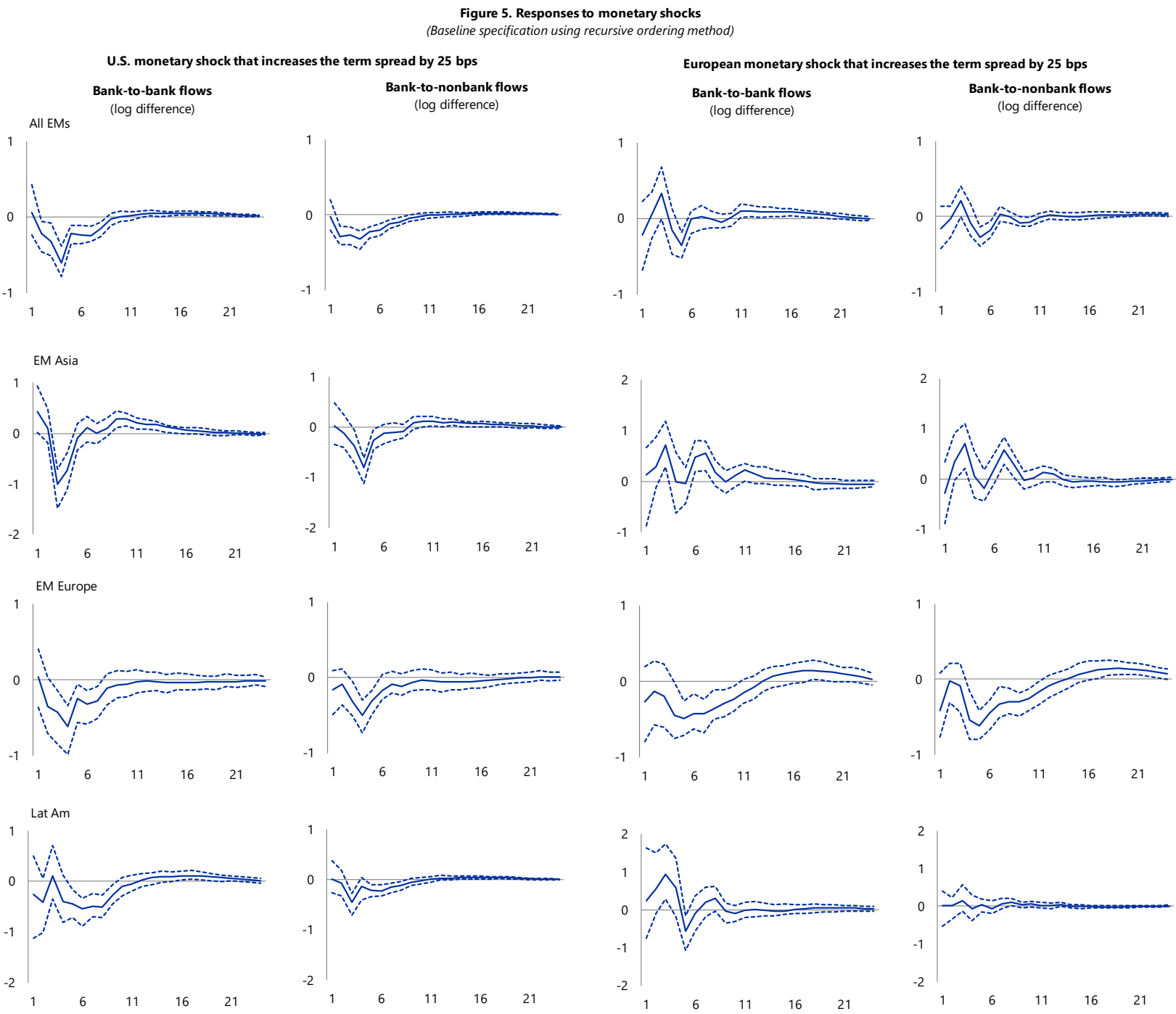

The solid line represents the point estimate, and the dashed lines represnt the 90 percent condifence interval.

These results are broadly consistent across different model specifications, using the real policy rate as the monetary policy variable, or the TED spread as the bank balance sheet variable, or both (see Table 4, columns 1-8)). As an additional robustness exercise, we estimate the preferred model using cross-border lending from the US to assess the effects of a US monetary shock (Table 4, column 9), and a proxy for cross-border lending from the Europe to examine the effects form a monetary shock originated in the EA (Table 4, column 10). The results are, again, consistent with what we find in the main two specifications using sign restrictions, but the responses tend to be larger in magnitude even than the base specification with recursive ordering for identification, as the sensitivity to US or EA shocks is larger for cross-border lending flows from those respective countries. 
Table 4. Responses of cross-border lending to emerging economies to monetary shocks

(qoq log-difference)

\begin{tabular}{|c|c|c|c|c|c|c|c|c|c|c|}
\hline & \multicolumn{2}{|c|}{$\begin{array}{l}\text { Baseline: Term spread shock } \\
\text { (bank leverage) 1/ }\end{array}$} & \multicolumn{2}{|c|}{$\begin{array}{l}\text { Term spread shock } \\
\text { (ted spread) } 1 /\end{array}$} & \multicolumn{2}{|c|}{$\begin{array}{l}\text { Real policy rate shock } \\
\text { (ted spread) 2/ }\end{array}$} & \multicolumn{2}{|c|}{$\begin{array}{c}\text { Real policy rate shock } \\
\text { (bank leverage) 2/ }\end{array}$} & \multirow{2}{*}{$\begin{array}{l}\text { US term } \\
\text { spread shock } \\
\text { (bank } \\
\text { leverage, } \\
\text { US flows) 1/ } \\
\text { (9) }\end{array}$} & \multirow{2}{*}{$\begin{array}{c}\text { EU term } \\
\text { spread shock } \\
\text { (bank } \\
\text { leverage, } \\
\text { EU-proxy } \\
\text { flows) 1/ } \\
\text { (10) }\end{array}$} \\
\hline & us & (2) & $\begin{array}{l}\text { US } \\
\text { (3) }\end{array}$ & (4) & $\begin{array}{l}\text { US } \\
\text { (5) }\end{array}$ & $\begin{array}{l}E A \\
\text { (6) }\end{array}$ & $\begin{array}{l}\text { US } \\
\text { (7) }\end{array}$ & $\begin{array}{l}E A \\
\text { (8) }\end{array}$ & & \\
\hline \multicolumn{11}{|l|}{ All EMs } \\
\hline \multicolumn{11}{|c|}{ Bank-to-bank flows } \\
\hline Impact & 0.063 & -0.212 & 0.021 & $-0.443 *$ & $-0.298 *$ & $-0.680 *$ & $-0.345 *$ & $-0.606 *$ & -0.340 & -0.144 \\
\hline 2nd quarter & $-0.214 *$ & 0.062 & -0.184 & 0.210 & 0.072 & $-0.580 *$ & -0.028 & $-0.441 *$ & $-1.058 *$ & 0.034 \\
\hline 4th quarter & $-0.608 *$ & -0.147 & $-0.606 *$ & -0.011 & $0.190 *$ & $0.456 *$ & $0.178 *$ & $0.555 *$ & $-1.477 *$ & $-0.299 *$ \\
\hline 8th quarter & $-0.151 *$ & -0.007 & $-0.242 *$ & -0.007 & 0.032 & -0.073 & -0.005 & -0.064 & 0.256 & -0.036 \\
\hline \multicolumn{11}{|c|}{ Bank-to-nonbank flows } \\
\hline Impact & -0.020 & -0.160 & -0.047 & -0.141 & $-0.128 *$ & $-0.383 *$ & $-0.143 *$ & $-0.449 *$ & -0.676 & -0.182 \\
\hline 2nd quarter & $-0.284 *$ & -0.029 & $-0.301 *$ & -0.177 & $0.077^{*}$ & 0.006 & 0.030 & -0.153 & -0.245 & -0.101 \\
\hline 4th quarter & $-0.323 *$ & -0.087 & $-0.303^{*}$ & 0.000 & $0.228 *$ & $0.506 *$ & $0.209 *$ & $0.468^{*}$ & 0.037 & -0.171 \\
\hline 8th quarter & $-0.093 *$ & 0.000 & $-0.146^{*}$ & 0.002 & 0.004 & 0.019 & -0.018 & $-0.104^{*}$ & 0.090 & 0.004 \\
\hline \multicolumn{11}{|l|}{ EM Asia } \\
\hline \multicolumn{11}{|c|}{ Bank-to-bank flows } \\
\hline Impact & $0.429 *$ & 0.137 & 0.452 & 0.264 & $-0.540 *$ & $-1.634 *$ & $-0.569 *$ & $-1.183 *$ & 0.452 & 0.231 \\
\hline 2nd quarter & 0.100 & 0.291 & 0.053 & 0.089 & 0.034 & -0.427 & -0.093 & $-0.614 *$ & 0.053 & -0.084 \\
\hline 4th quarter & $-0.739 *$ & -0.011 & $-0.716^{*}$ & 0.082 & $0.264 *$ & $0.807^{*}$ & $0.275 *$ & $0.850 *$ & $-0.716 *$ & -0.045 \\
\hline 8th quarter & 0.107 & 0.178 & 0.015 & 0.002 & -0.088 & -0.232 & -0.084 & -0.216 & 0.015 & 0.035 \\
\hline \multicolumn{11}{|c|}{ Bank-to-nonbank flows } \\
\hline Impact & 0.022 & -0.280 & 0.063 & -0.448 & $-0.247^{*}$ & $-0.838^{*}$ & $-0.250 *$ & $-0.842 *$ & 0.660 & -0.421 \\
\hline 2nd quarter & -0.125 & 0.347 & -0.160 & 0.174 & 0.170 & -0.348 & 0.118 & $-0.560 *$ & 0.280 & 0.292 \\
\hline 4th quarter & $-0.800 *$ & 0.055 & $-0.804 *$ & 0.022 & $0.339 *$ & $1.042 *$ & $0.369 *$ & $0.871 *$ & 0.202 & 0.063 \\
\hline 8th quarter & -0.094 & $0.287 *$ & -0.120 & 0.165 & $-0.066 *$ & 0.109 & -0.028 & -0.085 & 0.071 & $0.274^{*}$ \\
\hline \multicolumn{11}{|l|}{ EM Europe } \\
\hline \multicolumn{11}{|c|}{ Bank-to-bank flows } \\
\hline Impact & 0.039 & -0.263 & -0.119 & -0.195 & -0.079 & $-0.673 *$ & -0.155 & -0.429 & -0.690 & -0.492 \\
\hline 2nd quarter & -0.351 & -0.128 & $-0.608 *$ & -0.155 & $0.197^{*}$ & -0.392 & 0.083 & -0.187 & -1.120 & -0.201 \\
\hline 4th quarter & $-0.619 *$ & $-0.446 *$ & $-0.681 *$ & -0.155 & $0.148 *$ & -0.004 & 0.049 & 0.262 & -0.565 & $-0.590 *$ \\
\hline 8th quarter & -0.107 & $-0.357^{*}$ & $-0.432 *$ & -0.196 & $0.196 *$ & -0.113 & 0.017 & 0.047 & $1.608^{*}$ & $-0.408 *$ \\
\hline \multicolumn{11}{|c|}{ Bank-to-nonbank flows } \\
\hline Impact & -0.157 & -0.414 & -0.292 & -0.190 & 0.016 & -0.138 & -0.038 & -0.105 & $-2.608 *$ & $-0.557 *$ \\
\hline 2nd quarter & -0.087 & -0.019 & -0.177 & -0.149 & 0.071 & -0.242 & -0.013 & $-0.319 *$ & -0.460 & $-0.495 *$ \\
\hline 4th quarter & $-0.500 *$ & $-0.537 *$ & $-0.461 *$ & -0.349 & $0.283 *$ & $0.365 *$ & $0.207^{*}$ & $0.442 *$ & 0.244 & $-0.793 *$ \\
\hline 8th quarter & -0.116 & $-0.297 *$ & $-0.375^{*}$ & -0.150 & $0.139 *$ & -0.150 & 0.006 & -0.145 & $0.564 *$ & $-0.284 *$ \\
\hline \multicolumn{11}{|l|}{ Lat Am } \\
\hline \multicolumn{11}{|c|}{ Bank-to-bank flows } \\
\hline Impact & -0.253 & 0.250 & -0.324 & -0.613 & $-0.507^{*}$ & -0.916 & $-0.565 *$ & $-1.389 *$ & -0.324 & -0.087 \\
\hline 2nd quarter & -0.408 & 0.560 & -0.138 & $0.807 *$ & 0.196 & -0.674 & 0.071 & -0.906 & -0.138 & 0.435 \\
\hline 4th quarter & -0.401 & 0.584 & $-0.431 *$ & 0.443 & $0.294 *$ & $0.781 *$ & $0.330 *$ & 0.750 & $-0.431 *$ & 0.214 \\
\hline 8th quarter & $-0.500 *$ & 0.299 & $-0.475^{*}$ & 0.249 & 0.074 & -0.127 & 0.064 & -0.209 & $-0.475 *$ & 0.089 \\
\hline \multicolumn{11}{|c|}{ Bank-to-nonbank flows } \\
\hline Impact & 0.003 & 0.016 & 0.004 & 0.138 & $-0.177^{*}$ & $-0.557^{*}$ & $-0.183 *$ & $-0.551 *$ & $-0.817^{*}$ & 0.033 \\
\hline 2nd quarter & -0.068 & 0.022 & -0.107 & -0.189 & 0.016 & -0.066 & -0.040 & -0.322 & -0.376 & $-0.279 *$ \\
\hline 4th quarter & -0.134 & -0.071 & -0.114 & -0.111 & $0.169 *$ & 0.285 & $0.177^{*}$ & $0.259 *$ & -0.172 & $-0.330 *$ \\
\hline 8th quarter & $-0.112 *$ & $0.108 *$ & $-0.114 *$ & 0.080 & -0.005 & -0.066 & -0.018 & -0.132 & $-0.183 *$ & 0.017 \\
\hline
\end{tabular}




\section{Real shocks}

The effect of real positive shocks on cross-border lending is overall positive. This positive effect is likely a byproduct of: the decline in the term spread, the impact of larger domestic output on core countries' bank balance sheets, as well as the appreciation of EMs' currencies. As was the case in the large sign-restricted model without the financial sector, we also find that the effects on cross-border lending to EM are larger and more statistically significant when the shock originates in the EA rather than in the US (see Figure 6). The positive effect of the US or EA real positive shock seems not as large in the case of cross-border lending to Asian EMs. These results are robust across most alternative specifications as shown in Table 5. In general, unlike the case of the sign restriction model with the financial sector, AE real sector shocks seem to be more important than US shocks, but here the universal nature of European banks adds complexity to the analysis (making it more difficult to separate financial shocks from real shocks).

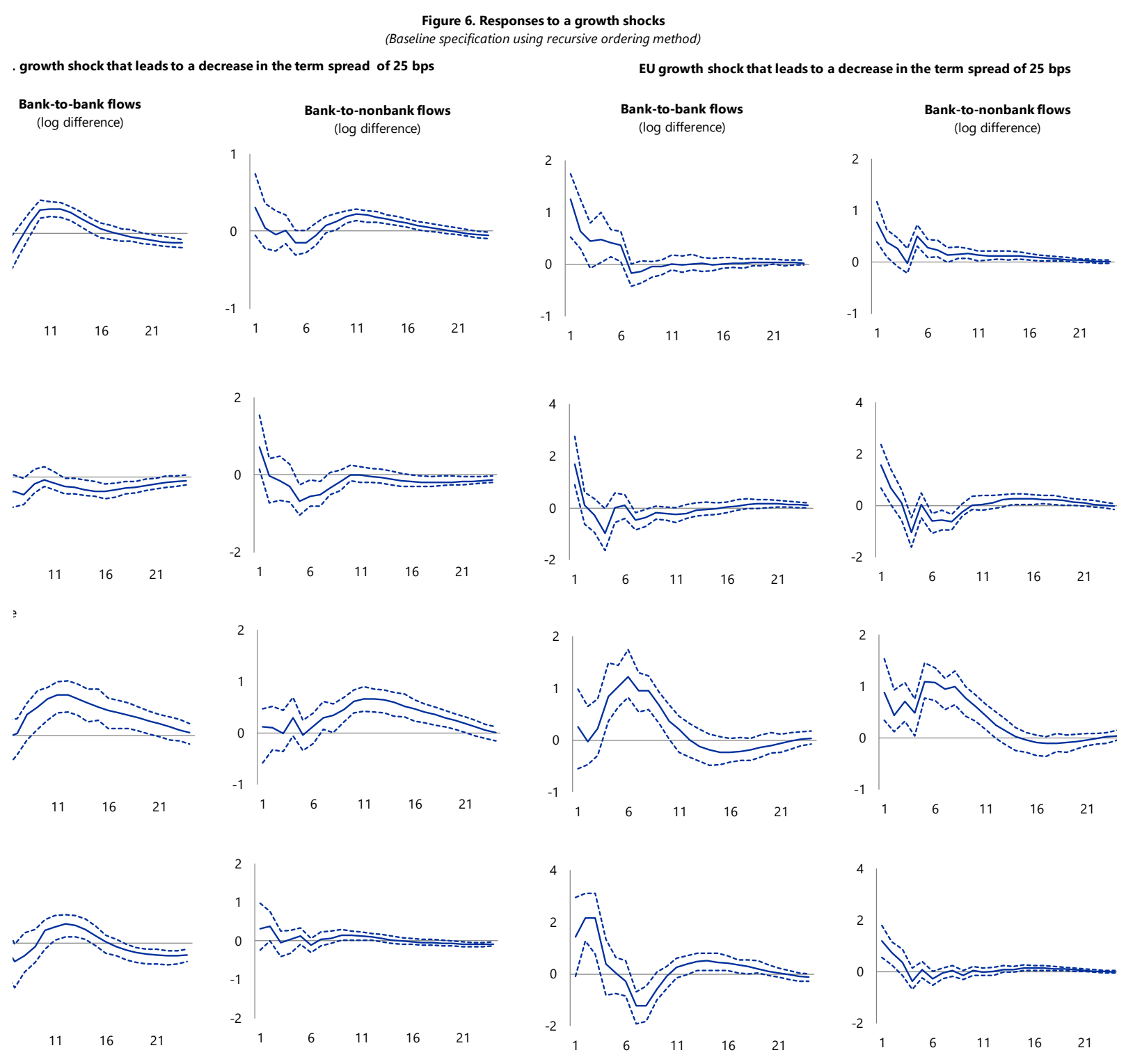

presents the point estimate, and the dashed lines represnt the 90 percent condifence interval. 
Table 5. Responses of cross-border lending to emerging economies to real shocks

(qoq log-difference)

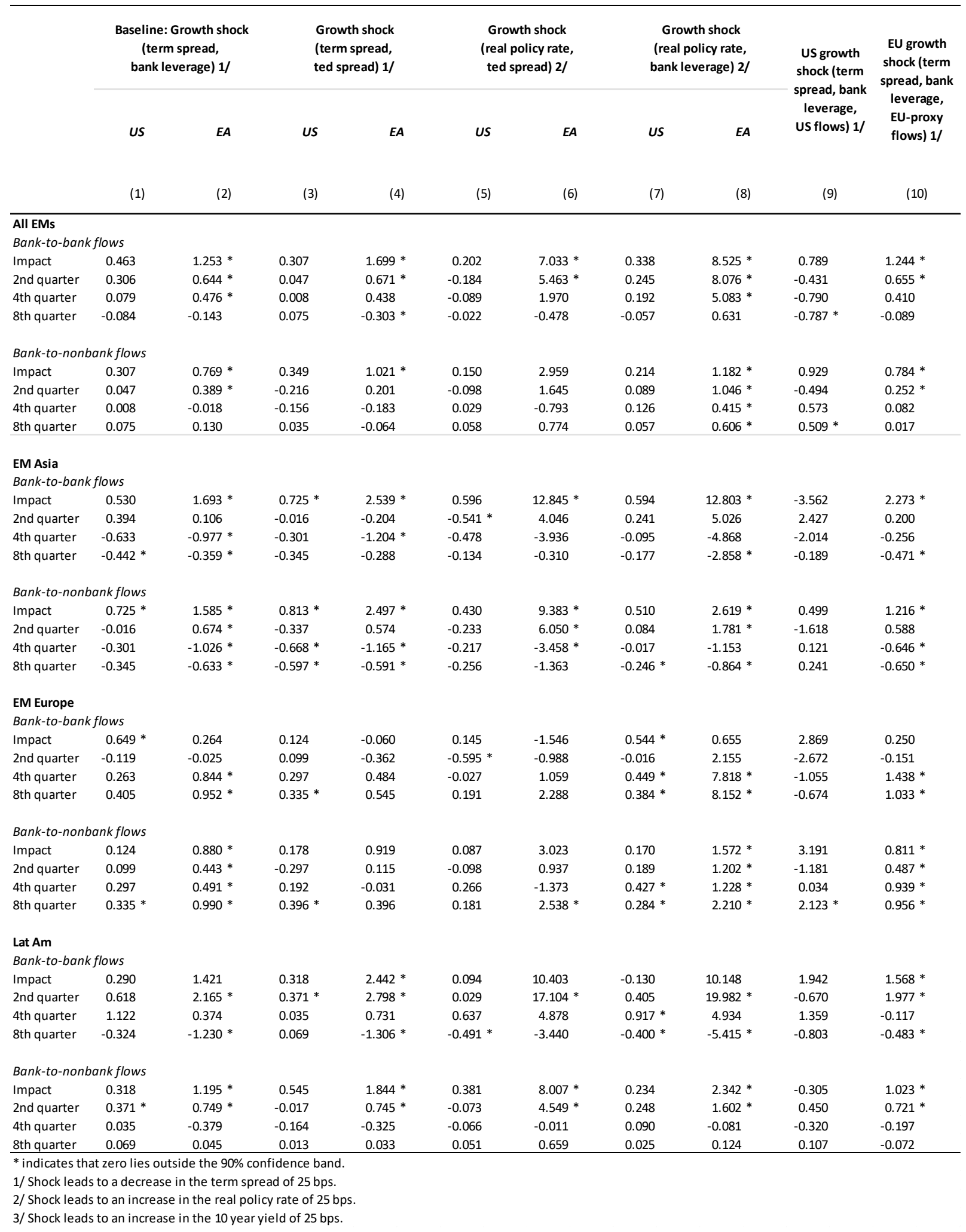




\section{Financial shocks}

Although displaying some smaller magnitudes, the results using the recursive ordering approach confirm to a large degree our previous findings when using the more comprehensive estimation of financial shocks. The results in the case of a negative financial shock that reduces bank leverage, which can be associated with stricter financial regulation that restricts the domestic supply of credit (e.g., through an increase in capital requirements) or the demand of credit (e.g., increase in LTVs), are also not as similar if originating in the US or EA. As shown in Figure 7, an increase in US financial leverage triggers a reduction of cross-border lending to EMs in both the bank and no-bank borrowing sectors. The regional breakdown shows that this effect is present across the three regions, and especially in the case of Emerging European borrowers. These results seem broadly consistent across alternative specifications as shown in columns (3), (5), (7) and (9) of Table 6.

\footnotetext{
Figure 7. Responses to financial shocks
}

(Baseline specification using recursive ordering method)

European bank leverage shock associated with an increase in the terms spread of 25 bps
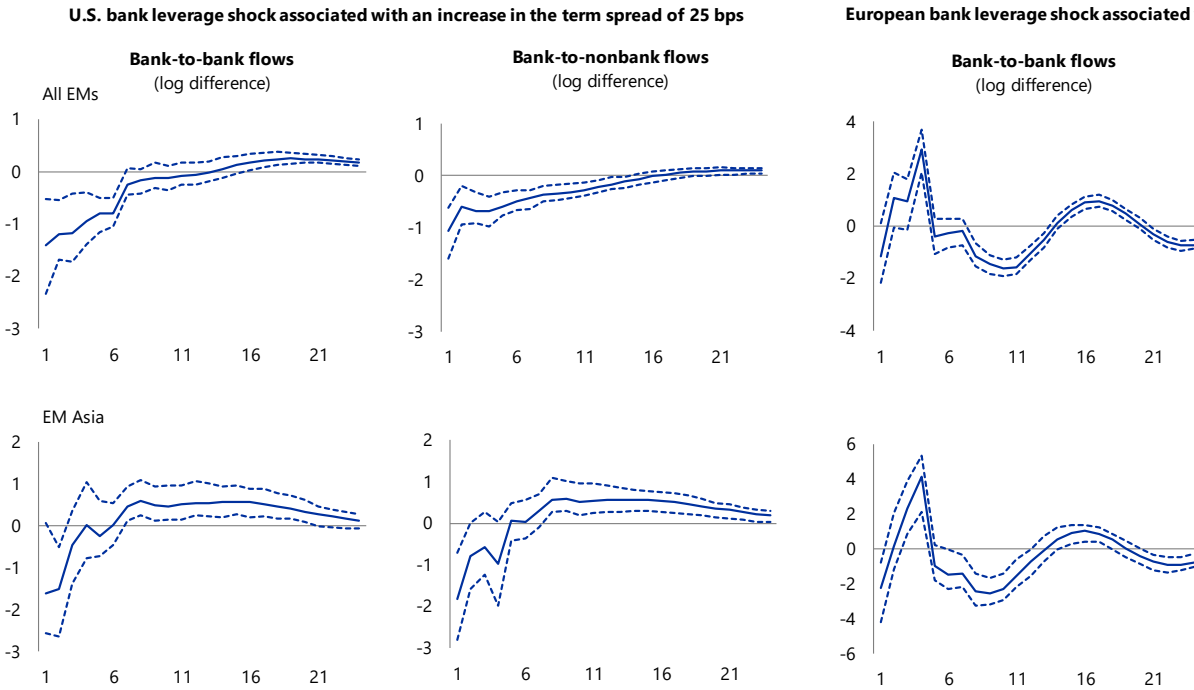

Bank-to-nonbank flows

flows (log difference)

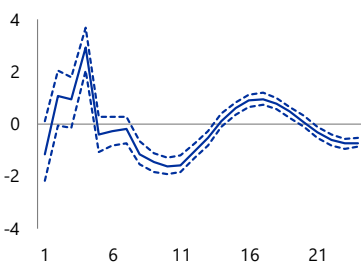
(log difference)

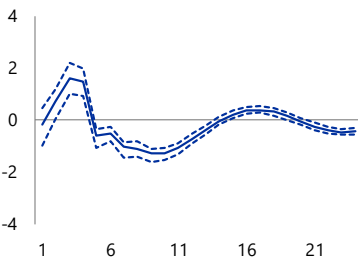

EM Europe
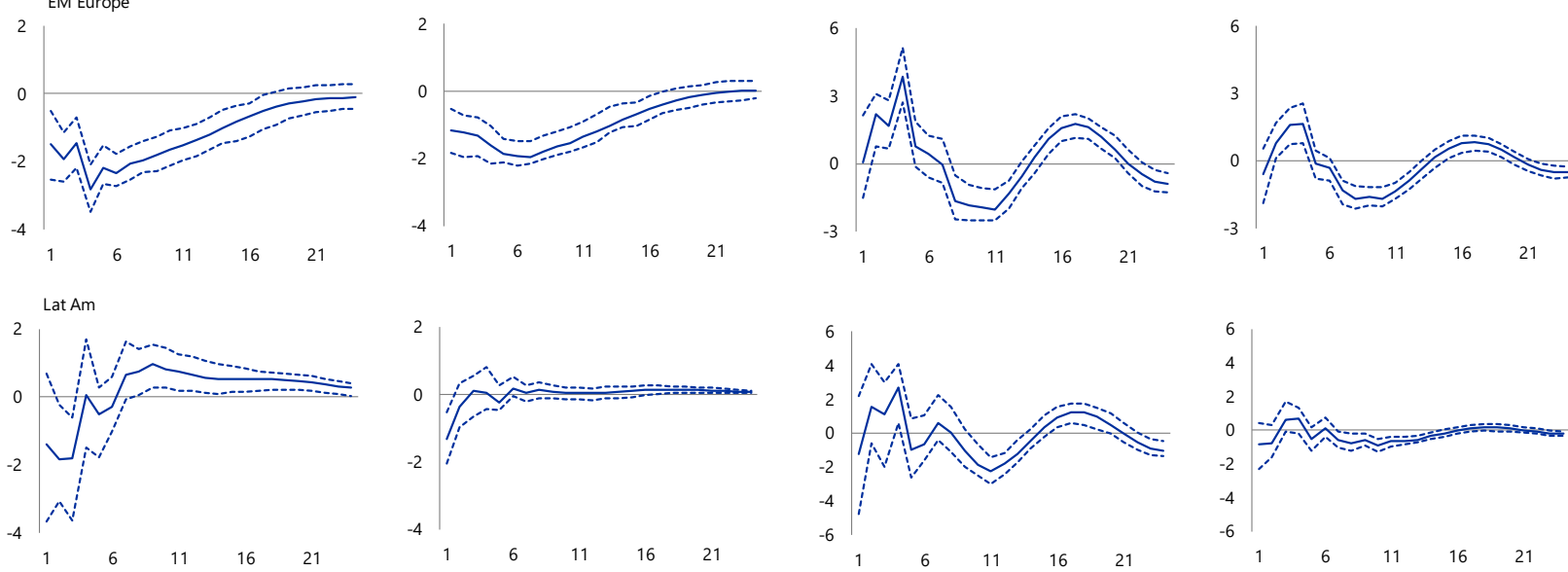
Table 6. Responses of cross-border lending to emerging economies to financial shocks (qoq log-difference)

\begin{tabular}{|c|c|c|c|c|c|c|c|c|c|c|}
\hline & \multicolumn{2}{|c|}{$\begin{array}{l}\text { Baseline: Bank leverage } \\
\text { (term spread) 1/ }\end{array}$} & \multicolumn{2}{|c|}{$\begin{array}{c}\text { Ted Spread } \\
\text { (term spread) 2/ }\end{array}$} & \multicolumn{2}{|c|}{$\begin{array}{c}\text { Ted Spread } \\
\text { (real policy rate) 2/ }\end{array}$} & \multicolumn{2}{|c|}{$\begin{array}{c}\text { Bank leverage } \\
\text { (real policy rate) 1/ }\end{array}$} & \multirow{2}{*}{$\begin{array}{c}\text { US bank } \\
\text { leverage } \\
\text { shock } \\
\text { (term spread, } \\
\text { US flows) 1/ }\end{array}$} & \multirow{2}{*}{$\begin{array}{l}\text { EU bank } \\
\text { leverage } \\
\text { shock } \\
\text { (term spread, } \\
\text { EU-proxy } \\
\text { flows) } 1 \text { / }\end{array}$} \\
\hline & US & EA & US & EA & US & EA & US & EA & & \\
\hline & (1) & $(2)$ & (3) & (4) & (5) & (6) & (7) & (8) & (9) & (10) \\
\hline \multicolumn{11}{|l|}{ All EMs } \\
\hline \multicolumn{11}{|c|}{ Bank-to-bank flows } \\
\hline Impact & $-1.417 *$ & -1.141 & $-1.057 *$ & $-1.067 *$ & $-2.595 *$ & $-1.737 *$ & $-3.219 *$ & -1.456 & -1.397 & -1.469 \\
\hline 2nd quarter & $-1.198 *$ & 1.090 & $-0.646 *$ & -0.195 & $-1.030 *$ & -0.824 & $-1.757 *$ & -0.193 & -0.874 & 0.071 \\
\hline 4th quarter & $-0.944 *$ & $2.933 *$ & $-0.967 *$ & 0.419 & $-2.524 *$ & -0.633 & $-2.207^{*}$ & $3.016 *$ & $-4.029 *$ & $2.025 *$ \\
\hline 8th quarter & -0.164 & $-1.135 *$ & $-0.544 *$ & $0.495 *$ & $-1.000 *$ & 0.262 & -0.065 & 0.281 & 0.091 & $-1.241 *$ \\
\hline \multicolumn{11}{|c|}{ Bank-to-nonbank flows } \\
\hline Impact & $-1.056 *$ & -0.166 & $-0.511 *$ & $-1.019 *$ & -0.627 & $-1.750 *$ & $-2.248 *$ & -0.278 & $-2.594 *$ & -0.406 \\
\hline 2nd quarter & $-0.589 *$ & $0.731 *$ & -0.086 & -0.144 & 0.166 & -0.348 & $-0.788 *$ & 0.296 & 0.827 & 0.204 \\
\hline 4th quarter & $-0.692 *$ & $1.496 *$ & $-0.295 *$ & $0.493 *$ & $-0.741 *$ & 0.111 & $-1.644 *$ & $1.342 *$ & 0.021 & $1.324 *$ \\
\hline 8th quarter & $-0.363 *$ & $-1.121 *$ & $-0.374 *$ & $0.414 *$ & $-0.714^{*}$ & $0.492 *$ & $-0.697^{*}$ & -0.234 & -0.027 & $-0.920 *$ \\
\hline \multicolumn{11}{|l|}{ EM Asia } \\
\hline \multicolumn{11}{|c|}{ Bank-to-bank flows } \\
\hline Impact & -1.623 & $-2.258 *$ & $-1.694 *$ & $-2.484 *$ & $-4.265 *$ & $-5.085 *$ & $-3.781 *$ & $-3.837^{*}$ & -3.519 & -2.279 \\
\hline 2nd quarter & $-1.505 *$ & 0.134 & 0.176 & -0.638 & $1.841 *$ & -1.690 & -1.704 & -2.117 & 0.430 & 0.786 \\
\hline 4th quarter & 0.026 & $4.145 *$ & -0.105 & $1.731 *$ & -0.850 & 1.465 & -0.574 & $4.916^{*}$ & $-5.326 *$ & $3.851 *$ \\
\hline 8th quarter & $0.607 *$ & $-2.448 *$ & -0.110 & $1.169 *$ & $-1.307^{*}$ & $1.312 *$ & 0.828 & 0.050 & 0.607 & $-2.316 *$ \\
\hline \multicolumn{11}{|c|}{ Bank-to-nonbank flows } \\
\hline Impact & $-1.836 *$ & -0.866 & $-0.988 *$ & $-1.696 *$ & -1.417 & $-3.500 *$ & $-4.255^{*}$ & -0.694 & -0.761 & -0.943 \\
\hline 2nd quarter & -0.805 & 1.073 & -0.227 & 0.080 & -0.407 & -0.178 & -0.869 & 0.658 & $4.772 *$ & 0.842 \\
\hline 4th quarter & -0.987 & $3.084 *$ & -0.202 & 0.996 & -0.896 & 0.685 & $-2.283 *$ & $3.279 *$ & 0.398 & $2.589 *$ \\
\hline 8th quarter & $0.553 *$ & $-1.284 *$ & 0.169 & $1.046 *$ & 0.151 & $1.334 *$ & $1.073 *$ & 0.484 & 0.525 & $-1.249 *$ \\
\hline \multicolumn{11}{|l|}{ EM Europe } \\
\hline \multicolumn{11}{|c|}{ Bank-to-bank flows } \\
\hline Impact & $-1.481 *$ & 0.076 & -0.568 & $-1.826 *$ & -0.993 & $-2.955^{*}$ & $-2.722 *$ & -0.221 & 0.925 & -1.570 \\
\hline 2nd quarter & $-1.927 *$ & $2.176 *$ & $-0.643 *$ & $-1.060 *$ & -0.684 & -2.190 & $-3.474 *$ & 0.852 & -4.164 & 0.928 \\
\hline 4th quarter & $-2.815^{*}$ & $3.864 *$ & $-1.494 *$ & $-1.110 *$ & $-3.369 *$ & $-3.434 *$ & $-6.132 *$ & $4.110^{*}$ & $-6.000 *$ & $2.618 *$ \\
\hline 8th quarter & $-1.962 *$ & $-1.621 *$ & $-1.234 *$ & 0.259 & $-2.587^{*}$ & -0.285 & $-3.702 *$ & 0.508 & -1.400 & $-1.862 *$ \\
\hline \multicolumn{11}{|c|}{ Bank-to-nonbank flows } \\
\hline Impact & $-1.165 *$ & -0.608 & -0.153 & $-1.280 *$ & -0.090 & $-2.107^{*}$ & $-2.490 *$ & -0.678 & $-8.986 *$ & -0.843 \\
\hline 2nd quarter & $-1.219 *$ & $0.805^{*}$ & 0.174 & $-0.852 *$ & 0.910 & $-1.836 *$ & $-2.008 *$ & 0.232 & -1.941 & 0.441 \\
\hline 4th quarter & $-1.604 *$ & $1.631 *$ & $-0.422 *$ & 0.478 & -0.872 & 0.043 & $-3.595 *$ & $1.627 *$ & 0.755 & 0.842 \\
\hline 8th quarter & $-1.782 *$ & $-1.695 *$ & $-1.043 *$ & $0.333 *$ & $-1.985 *$ & 0.285 & $-3.505 *$ & -0.392 & $-1.859 *$ & $-1.459 *$ \\
\hline \multicolumn{11}{|l|}{ Lat Am } \\
\hline \multicolumn{11}{|c|}{ Bank-to-bank flows } \\
\hline Impact & -1.385 & -1.216 & $-1.693 *$ & -1.373 & -4.310 & -1.534 & -2.387 & -0.425 & 0.656 & -0.893 \\
\hline 2nd quarter & $-1.837 *$ & 1.524 & -1.269 & 0.727 & -2.718 & 0.917 & -3.042 & 1.566 & $-4.014 *$ & -0.744 \\
\hline 4th quarter & 0.063 & $2.671 *$ & -1.241 & 1.312 & $-3.197 *$ & 0.881 & 0.434 & 2.162 & $-5.494 *$ & 1.481 \\
\hline 8th quarter & $0.749 *$ & 0.060 & -0.342 & 0.397 & 0.577 & -0.104 & $2.603 *$ & 0.595 & 0.543 & 0.021 \\
\hline \multicolumn{11}{|c|}{ Bank-to-nonbank flows } \\
\hline Impact & $-1.328 *$ & -0.816 & $-0.934 *$ & -0.417 & $-2.194 *$ & -0.947 & $-2.872 *$ & -0.736 & -1.340 & -0.841 \\
\hline 2nd quarter & -0.365 & -0.736 & 0.164 & -0.125 & 0.837 & -0.301 & -0.164 & -1.541 & -0.747 & -0.641 \\
\hline 4th quarter & 0.046 & 0.721 & 0.206 & 0.617 & 0.435 & 0.808 & 0.006 & 0.330 & -0.058 & 0.467 \\
\hline 8th quarter & 0.130 & $-0.755 *$ & $-0.410 *$ & 0.450 * & $-0.764 *$ & 0.302 & $0.435 *$ & -0.100 & $0.554 *$ & -0.334 \\
\hline
\end{tabular}

However, a negative financial shock in the EA financial sector has even translated into an increase in cross-border lending mostly to Emerging Europe and Asian EMs. These results seem broadly consistent across alternative specifications as shown in columns (4), (6), (8) and (10) of Table 6. It is not clear what could be driving these results. One alternative could be that the macroprudential measures being implemented in EA were of a different nature than in the US. 
Macroprudential measures targeting borrowers (e.g. LTV) would not constraint banks from cross-border lending. ${ }^{15}$

\section{Conclusions}

The simultaneous analysis of the role of monetary, real, and financial shocks in both the US and the EA shows some interesting results that are robust to two different identification procedures (recursive ordering and simultaneous sign restrictions) as well as numerous different specifications in the panel VARs. We corroborate the negative impact of US monetary policy tightening on cross-border lending to EMs, but we find that EA monetary policy seems to have an impact mostly on Emerging Europe. This captures well the fact that cross-border lending is mostly denominated in US dollars for the non-European EMs in our sample, and it also highlights the role of the exchange rate mismatches as a key transition channel. Along the lines stressed by Bruno and Shin (2015a), an appreciation of the EM currency vis-à-vis the currency denomination used in cross-border lending would improve the riskiness of the borrowers, so favoring an increase in cross-border lending. We also find that real sector shocks in both the US and EA trigger an increase in cross-border lending, especially when the shock originates in EA.

Finally, for financial sector shocks, our results indicate an overall contraction of cross-border lending in the case of US shocks, but this is not uniform across all borrowers when considering AE financial shocks. This highlights the complexity of what we are capturing within the financial shocks. For example, an increase in bank leverage can be the result of not only macroprudential policies targeting lenders (e.g., through an increase in general or specific capital requirements) but macroprudential policies targeting borrowers (e.g., through an increase in LTVs). The key question is what was the target of the policy makers. If they were targeting domestic vulnerabilities, it is logical to see an increase in cross-border lending. This is most likely the case for macroprudential policies targeting borrowers through LTV and DTI. However, most financial shocks captured by our analysis seem to be related to more general measures, such as an increase in general capital requirements, which would reduce domestic and cross-border lending. Further research is needed in this area.

\footnotetext{
${ }^{15}$ See Cerutti and Zhou (2018) for a discussion on the impact of macroprudential measures on cross-border banking flows. Lenders' leverage ratio requirement, interbank exposure limit and foreign currency loan limit, in particular, are associated with a lower level of direct cross-border banking outflows.
} 


\section{References:}

Ahmed, Shaghil, and Andrei Zlate (2014), "Capital Flows to Emerging Market Economies: A Brave New World?" Journal of International Money and Finance 48 (PB): 221-48

Aiyar, S., C. Calomiris, and T. Wieladek (2014), "Does Macro-Prudential Regulation Leak? Evidence from a UK Policy Experiment," Journal of Money, Credit and Banking, vol 46 (1), pp. 181-214, February.

Avdjiev, S. and E. Takáts (2018), "Monetary policy spillovers and currency networks in crossborder bank lending," Review of Finance, XX.

Avdjiev, S., C. Koch, P. McGuire, and G. von Peter (2019), Transmission of Monetary Policy Through Global Banks: Whose Policy Matters? BIS Working Paper No 737.

Bernanke, B., and A. Blinder (1988), "Credit, Money, and Aggregate Demand." The American Economic Review, Vol. 78 (2), pp.435-9.

Brauning, F., and V. Ivashina (2017), "Monetary Policy and Global Banking”, NBER Working paper No 23316.

Bruno, V. and H. S. Shin (2015a) "Capita flows and the Risk-Taking channel of Monetary Policy” Journal of Monetary Economics 71, 119-132.

Bruno, V. and H. S. Shin (2015b) “Cross-Border Banking and Global Liquidity” Review of Economic Studies 82, 535-564.

Buch, C., and L. Goldberg, 2017. "Cross-Border Prudential Policy Spillovers: How Much? How Important? Evidence from the International Banking Research Network." International Journal of Central Banking, Vol. 13 (S1).

Calvo, G., L. Leiderman, and C. Reinhart (1996) "Inflows of Capital to Developing Countries in the 1990s" Journal of Economic Perspectives 10, 123-39.

Cerutti, E., 2015, "Drivers of cross-border banking exposures during the crisis," Journal of Banking and Finance, 55, 340-357.

Cerutti, E., G. Hale, and C. Minoiu, 2015, "Financial Crisis and the Composition of Cross-border Lending," Journal of International Money and Finance, 52, 60-81.

Cerutti, E., S. Claessens and L. Ratnovski (2017) "Global Liquidity and Cross-Border Bank Flows" Economic Policy, 32(89), 81-125.

Cerutti, E. and H. Zhou (2018) "Cross-border Banking and the Circumvention of Macroprudential and Capital Control Measures” IMF Working Paper 18/217

Cetorelli, N., and L. Goldberg (2012), "Banking Globalization and Monetary Transmission," Journal of Finance, 67(5), 1811-1843.

Correa, R., T. Paligorova, H. Sapriza, and A. Zlate (2016), “Cross-Border Bank Flows and Monetary Policy," mimeo, Federal Reserve Board.

Ehrmann, M., and M. Fratzscher. 2005. "Equal Size, Equal Role? Interest Rate Interdependence between the Euro Area and the United States." The Economic Journal 115 (506): 928-48.. 
Ehrmann, M., M. Fratzscher and R. Rigobon R., 2011. "Stocks, Bonds, Money Markets and Exchange Rates”, Journal of Applied Econometrics, 26, pp. 948-974.

Forbes, K. J., and F. E. Warnock (2012) 'Capital Flow Waves: Surges, Stops, Flight, and Retrenchment” Journal of International Economics 88, 235-251.

Fratzscher, M. (2012) "Capital Flows, Push versus Pull Factors and the Global Financial Crisis" Journal of International Economics 88, 341-356.

Giannetti, M., and L. Laeven, 2012. "The Flight Home Effect: Evidence from the Syndicated Loan Market During Financial Crises.” Journal of Financial Economics, Vol. 104, pp. 23-43.

Goldberg, L., 2002. "When is US Bank Lending to Emerging Markets Volatile?” NBER Chapters: 171-196.

Houston, J., C. Lin, and Y. Ma, 2012. "Regulatory Arbitrage and International Bank Flows." Journal of Finance, Vol. 76 (5), 1845-95.

Jeanneau, S. and M. Micu, 2002. "Determinants of international bank lending to emerging market countries.” BIS Working Paper No 112, June.

Koepke, R. (2015) "What Drives Capital Flows to Emerging Markets: A Survey of the Empirical Literature" IIF Working Paper, Washington, D.C.

Matheson, T., and E. Stavrev, 2014. "News and Monetary Shocks at a High Frequency: A Simple Approach.” Economics Letters 125 (2): 282-86..

McCauley, R., P. McGuire and V. Sushko, 2015. "Global dollar credit: links to US monetary policy and leverage.” Economic Policy, vol. 30, issue 82, pp. 187-229

Rey, Hélène (2013) "Dilemma not Trilemma: The Global Financial Cycle and Monetary Policy Independence" in Proceedings of the 2013 Federal Reserve Bank of Kansas City Economic Symposium at Jackson Hole, 285-333

Rey, Hélène (2015) "International Channels of Transmission of Monetary Policy and the Mundellian Trilemma," Mundell Fleming lecture, IMF Economic Review, May, 64(1), 6-35.

Rubio-Ramirez, J.F., D. Waggoner, and T. Zha, 2005, “Markov-Switching Structural Vector Autoregressions: Theory and Application," Federal Reserve Bank of Atlanta, Working Paper 2005-27.

Shin, H.S., 2012 “Global Banking Glut and Loan Risk Premium” Mundell-Fleming Lecture, IMF Economic Review 60 (2), 155-192

Turner, P., 2016. "Macroprudential Policies, the Long -Term Interest Rate and the Exchange Rate," BIS Working Papers no 588, October. 


\section{Appendix A - Evolution of the domestic variables and spillovers to EMs}

\section{Monetary shock}

A monetary shock in the baseline model leads to a reduction in domestic GDP growth, risk appetite and bank leverage on impact. While GDP growth starts to recover a few quarters after the shock ( 4 in the case of the EA and 6 in the case of the US), the negative effect on bank leverage is more protracted, lasting about 12 quarters in both countries (See top part of Figure A1). In other words, this type of shock increases the financing cost for firms and households, reducing the demand for credit, and thus GDP growth. Regarding the international effects, an exogenous increase in the term spread in either the US or EA leads to lower GDP growth and weaker currencies in emerging economies, but the effects fade after 6 quarters. The decline in aggregate demand in the US or EA brought about by the monetary tightening in these economies, reduces the demand of exports from emerging economies, thus adversely affecting their growth prospects and weakening their currencies (See bottom of Figure A1).

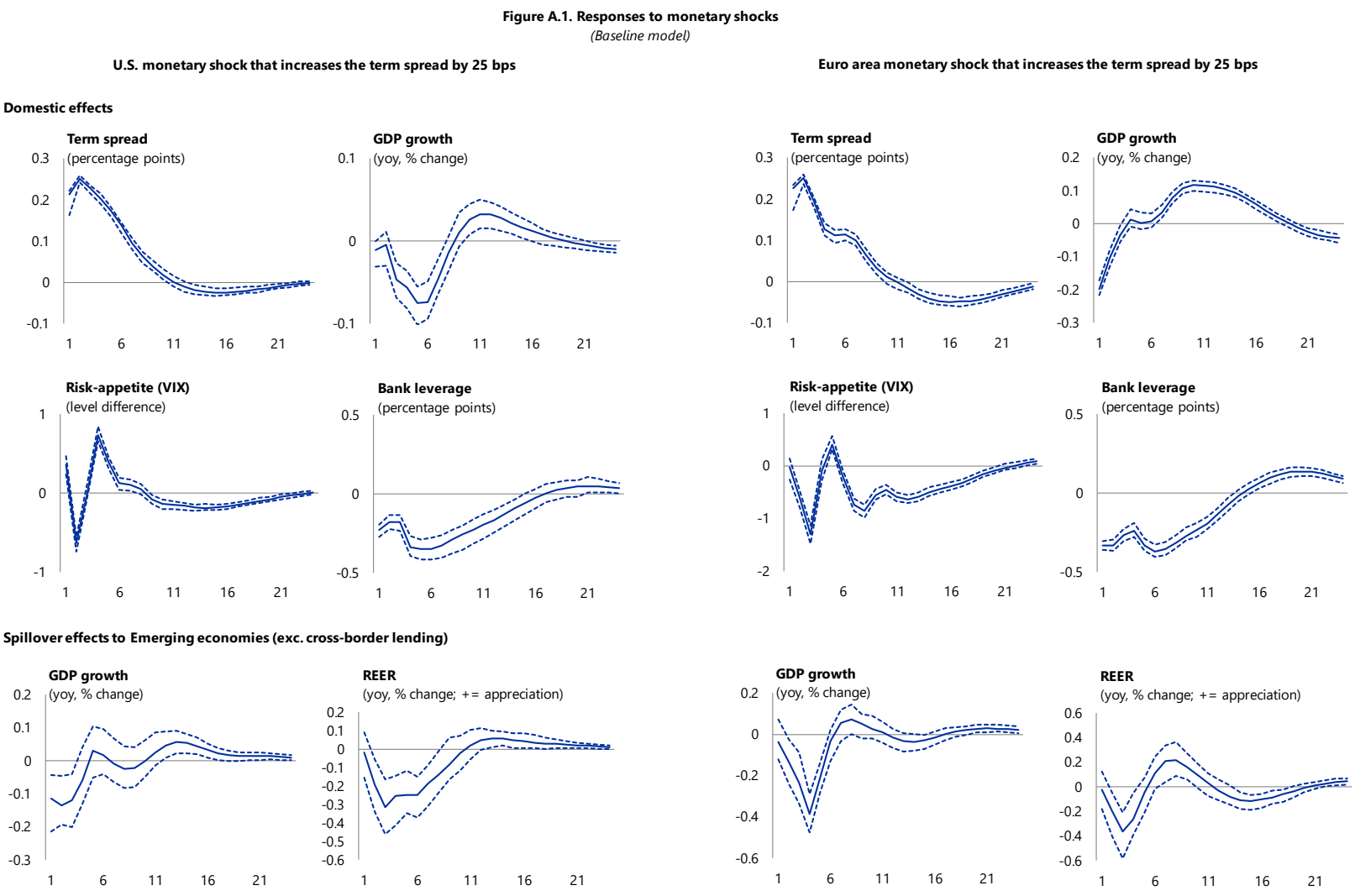

The solid line represents the point estimate, and the dashed lines represnt the 90 percent condifence interval.

\section{Growth shock}

Our results indicate that an autonomous shock to aggregate demand in the US or the EA leads to higher GDP growth, and increases the domestic demand for credit, inducing banks to leverageup to meet the additional demand for funds. Domestic risk-aversion declines in the first few quarters after the shock, reflecting agents' willingness to take more risk on the back of improved economic conditions. We also observe a decline in the domestic term-spread, as short-term rates 
likely increase due to countercyclical monetary policy, ${ }^{16}$ and they likely do so more than longterm rates, because these are affected by other long-term macroeconomic factors (e.g., savings productivity, etc.). Increased demand in the US or EA translates into to higher GDP growth rates in EMs, albeit with a lag (see Figure A.2).

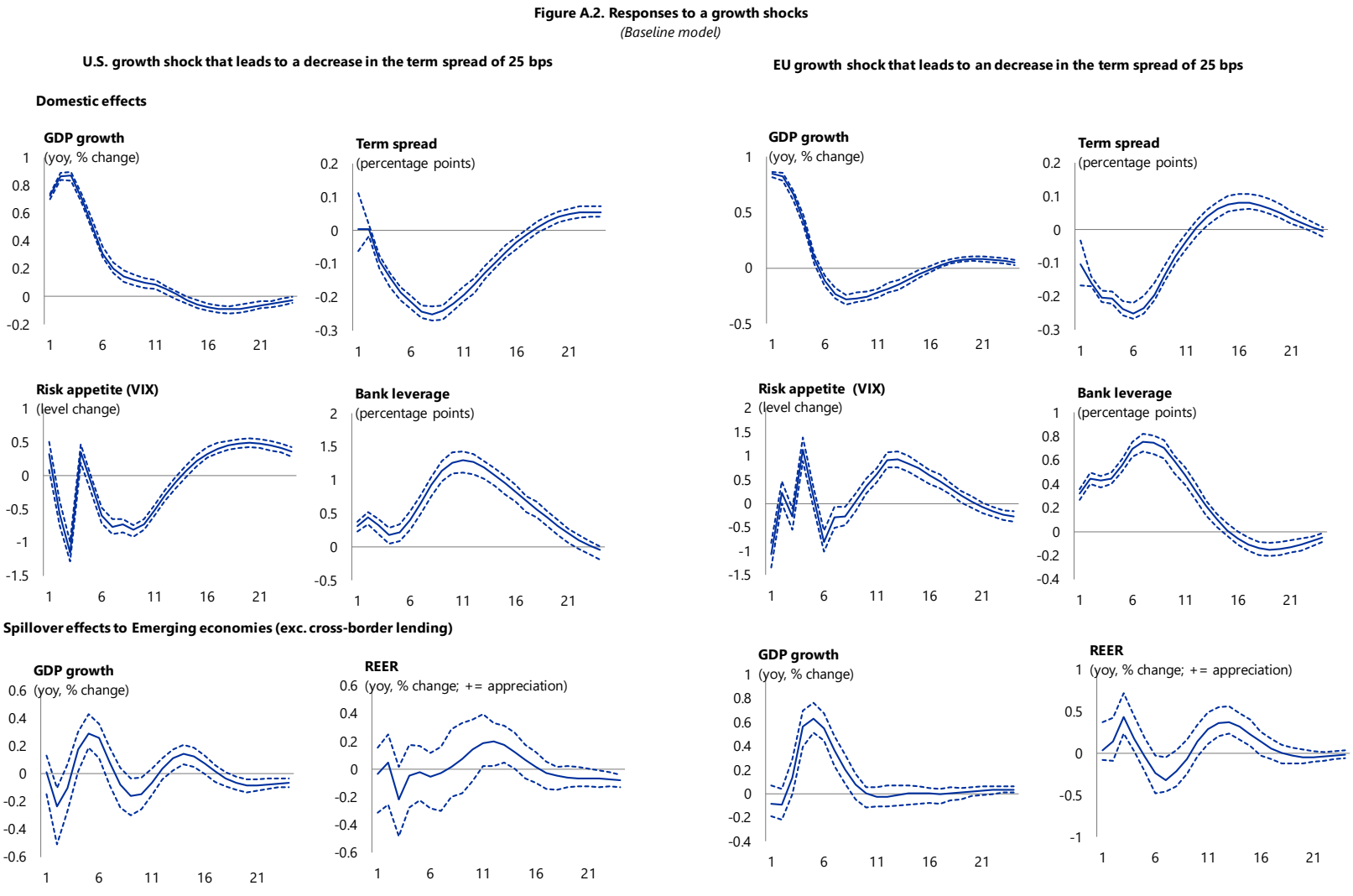

The solid line represents the point estimate, and the dashed lines represnt the 90 percent condifence interval.

\section{Financial shock}

A decline in leverage lead to a reduction in domestic GDP growth, as well as increases in risk appetite and term spread on impact. While US GDP growth starts to steadily recover a few quarters after the shock (6 quarters), the evolution in EA is more volatile (See top part of Figure A3). Regarding the international effects, an exogenous decline in leverage in either the US or EA leads to lower GDP growth, with the effects fading after a few years (See bottom of Figure A3).

\footnotetext{
16 The models where the monetary variable is the policy rate support this view, as they show that a shock to GDP growth leads to an increase in the policy rate.
} 
Figure A.3. Responses to financial shocks

(Baseline model)

U.S. bank leverage shock associated with an increse in the term spread of 25 bps Domestic effects

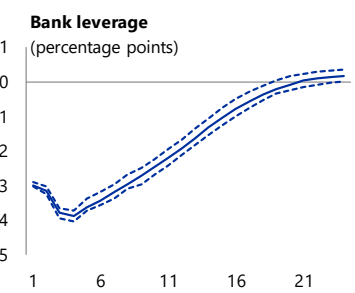

GDP growth

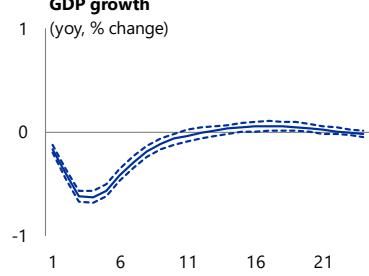

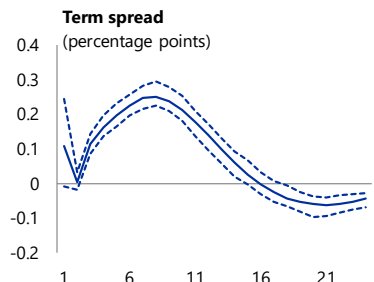

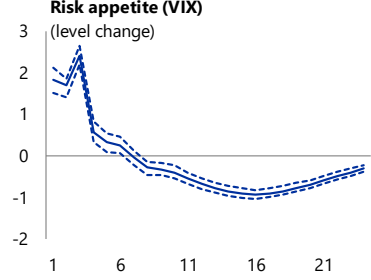

Risk appetite (VIX)
European bank leverage shock associated with an increase in the term spread of 25 bps
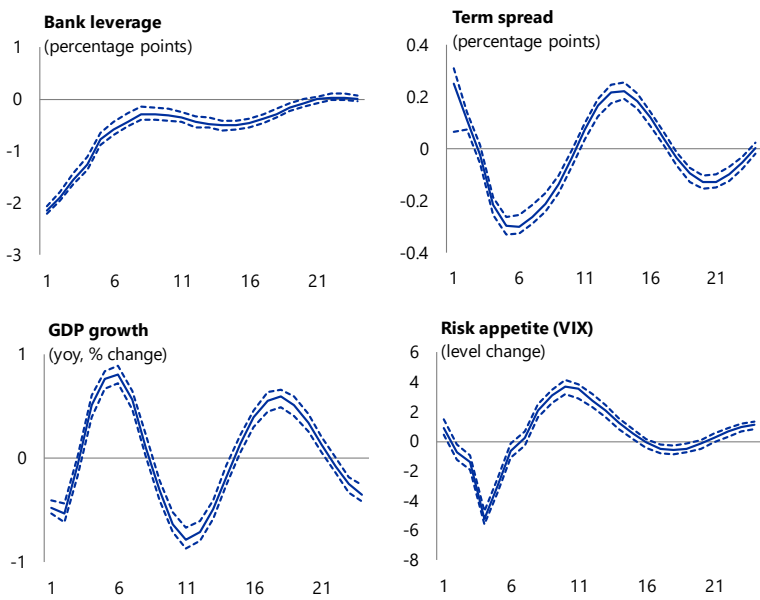

Spillover effects to Emerging economies (exc. cross-border lending)
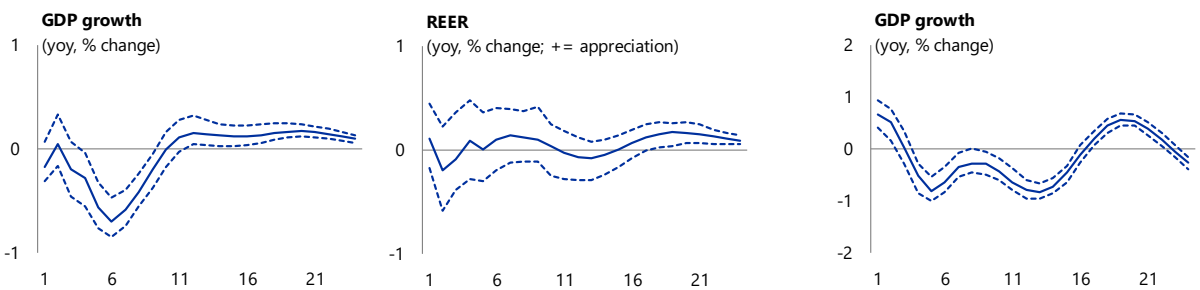

REER

1 (yoy, \% change; += appreciation)

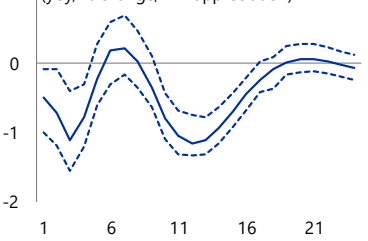

The solid line represents the point estimate, and the dashed lines represnt the 90 percent condifence interval. 
Table A1

\begin{tabular}{|c|c|c|}
\hline Variables & Definition & Sources \\
\hline \multicolumn{3}{|c|}{ Dependent variables } \\
\hline $\begin{array}{l}\text { Cross-border claims on banks } \\
\text { Cross-border claims on non-banks }\end{array}$ & $\begin{array}{l}\text { Log Change in BIS Locational Cross-Border Claims on Banks } \\
\text { (exchange rate adjusted) } \\
\text { Log Change in BIS Locational Cross-Border Claims on Non-Banks } \\
\text { (exchange rate adjusted) }\end{array}$ & $\begin{array}{l}\text { BIS Locational statistics } \\
\text { BIS Locational statistics }\end{array}$ \\
\hline \multicolumn{3}{|c|}{ Economic and financial conditions in financial center economies } \\
\hline US VIX & CBOE S\&P500 Volatility Index & Datastream \\
\hline EA VIX & VDAX Volatility Index (new) & Datastream \\
\hline US TED spread & 3-month TED spread (LIBOR - Treasury bill) & Datastream \\
\hline EA TED spread & 3-month Euro LIBOR spread (LIBOR - Govt. AAA bill) ${ }^{1 /}$ & Datastream \\
\hline US real policy rate & Federal Funds Target Rate & Haver \\
\hline EA real policy rate & Euro Area Deposit facitlity rate & Haver \\
\hline US slope of yield crurve & 10 year/3 month US Treasury yield spread & Datastream \\
\hline EA slope of yield curve & 10 year/3 month EA AAA Sovereign yield spread ${ }^{1 /}$ & Datastream \\
\hline US 10 year sovereign yield & 10 year US Treasury yield spread & Bloomberg \\
\hline EA 10 year sovereign yield & 10 year EA Sovereign yield spread & Bloomberg \\
\hline US stock prices & S\&P 500 Composite price index & Bloomberg \\
\hline EA stock prices & EURO STOXX price index & Bloomberg \\
\hline US broker-dealer leverage & (Equity+Total Liabilities)/Equity & US Flow of Funds \\
\hline Large EU banks leverage & Total Assets/Equity & Bankscope \\
\hline US lending rate & US 30 year fixed rate mortgages & Haver \\
\hline EA lending rate & EA new housing loans ${ }^{1 /}$ & Haver \\
\hline \multicolumn{3}{|c|}{ Borrower countries economic conditions } \\
\hline Real GDP Growth & Growth rate of real GDP & WEO \\
\hline Real effective exchange rate & Annual growth rate & WEO \\
\hline
\end{tabular}

Note: 1/ Data on Euro Government AAA 3-month bill is available since 2007, the period 1990-2006 is based on the 3 month French treasury bill rate. Data on Euro Area housing loans is avilable since 2000, the period 1990-99 is based on France's new housing loans variable rate. 